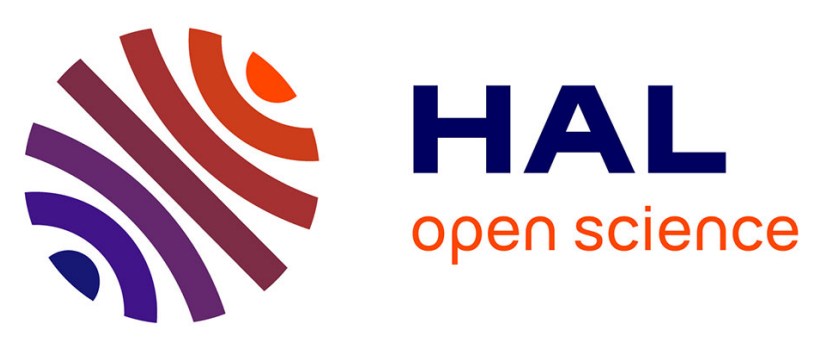

\title{
Evaluation of rammelsbergite (NiAs2) as a novel mineral for 187Re-187Os dating and implications for unconformity-related $U$ deposits
}

Stepan Chernonozhkin, Julien Mercadier, Laurie Reisberg, Béatrice Luais, Catherine Zimmermann, Christophe Morlot, Lise Salsi, Andreï Lecomte, Olivier Rouer, Marc Brouand, et al.

\section{To cite this version:}

Stepan Chernonozhkin, Julien Mercadier, Laurie Reisberg, Béatrice Luais, Catherine Zimmermann, et al.. Evaluation of rammelsbergite (NiAs2) as a novel mineral for 187Re-187Os dating and implications for unconformity-related U deposits. Geochimica et Cosmochimica Acta, 2020, 280, pp.85-101. 10.1016/j.gca.2020.04.011 . hal-02970170

\section{HAL Id: hal-02970170 \\ https://hal.univ-lorraine.fr/hal-02970170}

Submitted on 26 Nov 2020

HAL is a multi-disciplinary open access archive for the deposit and dissemination of scientific research documents, whether they are published or not. The documents may come from teaching and research institutions in France or abroad, or from public or private research centers.
L'archive ouverte pluridisciplinaire HAL, est destinée au dépôt et à la diffusion de documents scientifiques de niveau recherche, publiés ou non, émanant des établissements d'enseignement et de recherche français ou étrangers, des laboratoires publics ou privés. 
1 Evaluation of rammelsbergite $\left(\mathrm{NiAs}_{2}\right)$ as a novel mineral for ${ }^{187} \mathrm{Re}-{ }^{187} \mathrm{Os}$ dating and implications

\section{2 for unconformity-related $U$ deposits}

3

Stepan M. Chernonozhkin ${ }^{1,2}$, Julien Mercadier ${ }^{1 *}$, Laurie Reisberg ${ }^{2}$, Béatrice Luais ${ }^{2}$, Catherine

Zimmermann ${ }^{2}$, Christophe Morlot ${ }^{1}$, Lise Salsi $^{1}$, Andreї Lecomte ${ }^{1}$, Olivier Rouer ${ }^{1}$, Marc Brouand ${ }^{3}$, Amber

Doney $^{4}$, Patrick Ledru ${ }^{4}$

7

8

${ }^{1}$ Université de Lorraine, CNRS, CREGU, GeoRessources Lab, Campus Aiguillettes, Faculté des Sciences et Technologies, rue Jacques Callot, Vandoeuvre-lès-Nancy, F-54506, France

${ }^{2}$ Centre de Recherches Pétrographiques et Géochimiques (CRPG), CNRS, Université de Lorraine, UMR 7358, 15 rue Notre Dame des Pauvres, Vandoeuvre lès Nancy, F-54501, France

${ }^{3}$ Orano Mining, 1 place Jean Millier, 92400 Courbevoie, France

${ }^{4}$ Orano Canada Inc. 817 45th Street West, S7K 3X5 Saskatoon, Canada

* Corresponding author: julien.mercadier@univ-lorraine.fr

Stepan M. Chernonozhkin ORCID ID: 0000-0003-4521-0805;

\section{Abstract}

Rammelsbergite $\left(\mathrm{NiAs}_{2}\right)$ is often present in ore deposits worldwide in association with other arsenides, sulphides and sulfarsenides. This work demonstrates the value of the application of the Re-Os isotopic system to the dating of rammelsbergite. Using the example of the Cigar Lake uranium deposit (Athabasca Basin, Saskatchewan, Canada), our results show that rammelsbergite concentrates significant and variable amounts of Re when crystallizing, up to $1.6 \mu \mathrm{g} \mathrm{g}^{-1}$, while incorporating minimal common Os. Such characteristics make this mineral an ideal target for Re-Os isotopic dating, by both isochron and model age methods. Remarkable agreement of the Re-Os age of the rammelsbergite with the U-Pb age of the uranium oxide grains found inside one of the massive rammelsbergite veins confirms the applicability of the method. The selected rammelsbergite samples from the Cigar Lake uranium deposit yield a ${ }^{187} \mathrm{Re}-{ }^{187} \mathrm{Os}$ isochron age of $1239+33 /-20 \mathrm{Ma}$. These results challenge a longstanding petrogenetic model which postulates contemporaneous $\mathrm{U}$ oxide and $\mathrm{Ni}$-Co-arsenide deposition in unconformity-related uranium deposits. The new Re-Os age of rammelsbergite veins indicates that arsenide 
crystallization postdated the deposition of the primary uranium oxides at 1461-1341 Ma, implying that uranium oxides and nickel arsenides, as well as other sulphides and sulfarsenides, were not precipitated contemporaneously

32 during a single hydrothermal event as previously proposed. The ${ }^{187} \mathrm{Re}^{-187} \mathrm{Os}$ data suggest that crystallization of rammelsbergite and co-genetic sulphides, arsenides and sulfarsenides was linked to the ca. 1270 Ma Mackenzie magmatic event, marked by the emplacement of mafic dikes throughout the Canadian Shield, including in the area of the Athabasca Basin. This study therefore suggests a new hypothesis for the origin of nickel, cobalt, sulfur and arsenic in unconformity-related $\mathrm{U}$ deposits of the Athabasca Basin. More broadly, the successful application of the ${ }^{187} \mathrm{Re}^{187} \mathrm{Os}$ rammelsbergite chronometer in this geological context suggests that its application in other ore deposit environments worldwide is likely to provide similar insights. In this respect, the ${ }^{187} \mathrm{Re}^{-187} \mathrm{Os}$ chronometer applied to rammelsbergite, and potentially to other arsenides and sulfarsenides, represents a valuable complement to molybdenite dating because it can be used in systems that lack molybdenite.

41 Keywords: ${ }^{187} \mathrm{Re}^{187} \mathrm{Os}$, rammelsbergite, arsenide, unconformity-related, uranium deposit, Cigar Lake,

42 Mackenzie magmatic event 
The dating of mineral phases, including those of economic interest, is a key step for constraining their formation mechanisms and how these may have changed as the Earth evolved. Major progress has been made in the direct dating of metal-bearing phases (such as wolframite, cassiterite, columbite-tantalite or sulfides, notably molybdenite) in recent years, through both conventional and in-situ methods (Deng et al., 2019; Harlaux et al., 2018; Legros et al., 2019; Saintilan et al., 2017; Stein et al., 2001). Parallel to this improvement of dating orebearing minerals, there is growing interest in the so-called "critical metals", because of their importance in communication technologies, and in the energy and transport transitions which will drive the $21^{\text {st }}$ century. Nickel is one of these highly coveted metals so any new method allowing to temporally constrain Ni mineralization is a sought-after tool. Nickel sulfides and/or arsenides are particularly useful forms of economically exploitable Ni. Among these phases, rammelsbergite ( $\mathrm{NiAs}_{2}$, containing $28 \%$ nickel and $72 \%$ arsenic) is an uncommon mineral at a global scale, but is nevertheless formed in a wide range of geological settings (magmatic, metamorphic or hydrothermal) and is commonly found as disseminated grains or in the form of bulk veins in over 200 mining locations worldwide, including some world class districts. Rammelsbergite occurs as a minor component of nickeline-chromite ores in metaperidotite, i.e. Ni-Cr ores hosted in ultramafic rocks of the Beni Bousera massif of Morocco, or in the La Gallega and Los Jarales mines in Malaga province in Spain (Oen, 1973). Magmatic rammelsbergite is also described in nepheline-sodalite syenite plutonic rocks (naujaite) in the Ilimaussaq alkaline massif, South Greenland (Oen et al., 1977). Rammelsbergite, along with other arsenides and sulfarsenides, is a common mineral in metamorphosed $\mathrm{Ni}-\mathrm{Cu}-\mathrm{PGE}$ sulfide ores, such as the metamorphic-hydrothermal assemblages of disseminated Co-Ni-Cu ores of the Duluth Complex, Minnesota, USA (Raič et al., 2015), and Norilsk ore field (Gritsenko and Spiridonov, 2008). In this type of deposit, rammelsbergite and other arsenides co-crystallize from hydrothermal fluids that have reworked primary sulfides. Rammelsbergite is also a ubiquitous phase in several Ag-Bi-Ni-Co ore deposits of hydrothermal origin, in which it is found in association with other arsenides and sulfarsenides and with native silver and bismuth within carbonate veins. Typical examples of such associations include the Cobalt-Gowganda silver mining areas (Ontario, Canada) (Petruk, 1971), the five-element deposits of the Variscan belt (e.g. Jáchymov ore district, Czech Republic), deposits of the Odenwald and Niederschlema-Alberoda, Germany (Ondrus et al., 2003; Forster et al., 2004; Burisch et al., 2017), the KhovuAksy Co-Ni arsenide ores in Tuva, Russia (Bortnikova et al., 2012), and deposits of the Great Bear Lake region, Northwest Territories, Canada (Changkakoti and Morton, 1986). Rammelsbergite is also described in 
rammelsbergite is often found in association with uranium in the world class unconformity-related $\mathrm{U}$ deposits of the Athabasca Basin (Saskatchewan, Canada; Jefferson et al., 2007; Kyser and Cuney, 2015), for example, at the Key Lake (Carl et al., 1992), Moore Lake (Annesley et al., 2000), Cigar Lake and Midwest deposits (Reyx and Rulhmann, 1993). For these deposits and for numerous other $U$ occurrences throughout the Athabasca Basin, rammelsbergite is found in association with different arsenides and sulfarsenides within or in close vicinity to the uranium mineralization (Reyx and Rulhmann, 1993). Based on petrographic observations, rammelsbergite is suggested to be one of the primary arsenide minerals in a sequence of multiple arsenides and sulfarsenides, while nickeline, gesrdorfitte and cobaltite are considered to crystallize later but during the same global fluid event (Reyx and Rulhmann, 1993).

The widespread presence of rammelsbergite in many types of ore deposits makes this mineral an attractive target for Re-Os dating, compared to other arsenide minerals previously evaluated (Arne et al., 2001; Morelli et al., 2005; Morelli et al., 2007; Saintilan et al., 2017). Considering the example of unconformity-related Athabascan $\mathrm{U}$ deposits, the conditions of crystallization of the uranium mineralization are currently not entirely known, leading to loosely constrained genetic models for this major ore province. Several dating approaches, based on different target minerals (uranium oxides and clays), have been attempted to determine the timing and duration of fluid circulation episodes within the last $1.6 \mathrm{Ga}$ and their role in controlling the current shape of the uranium deposits. But the post-crystallization preservation of these phases and therefore of the isotopic systems used for dating is a recurrent problem leading to questionable results (Fryer and Taylor, 1984; Philippe et al., 1993; Fayek et al., 2002a; Martz et al., 2019b). In consequence, the links between tectono-thermal event(s), successive fluid circulations and potential episode(s) of metal deposition in the Athabasca Basin (Jefferson et al., 2007; Kyser and Cuney, 2015) are not fully established for this province, as for many other metalliferous provinces worldwide. In this study we evaluate the applicability of the ${ }^{187} \mathrm{Re}-{ }^{187} \mathrm{Os}$ rammelsbergite chronometer, using the example of the Cigar Lake U deposit, the archetype of unconformity-related U deposits. The new key temporal constraints provided by rammelsbergite dating for the formation and evolution of this deposit are used to demonstrate the potential utility of the rammelsbergite chronometer in the wide range of depositional environments in which this phase is found.

\section{Regional geology and geochronology of the Cigar Lake uranium deposit}

Detailed description of the geology at the regional, local and deposit scales and of the current metallogenic models for unconformity-related U deposits are provided in numerous publications, such as Reyx and Rulhmann (1993), Bruneton (1993), Pacquet and Weber (1993), Kotzer and Kyser (1995), Annesley et al. (2005), Jefferson et al. 

more details the reader is referred to the papers above.

The Cigar Lake deposit is a world-class uranium deposit located close to the eastern edge of the Athabasca Basin, in northern Saskatchewan, Canada. The deposit is lens-shaped and elongated in the E-W direction over $1.9 \mathrm{~km}$, and is 15 to $100 \mathrm{~m}$ wide and $10-20 \mathrm{~m}$ high. With $613,400 \mathrm{t}$ of uranium reserves at an average grade of $16.2 \% \mathrm{U}_{3} \mathrm{O}_{8}$ (Cameco, 2016), the Cigar Lake deposit is the world's second largest high-grade uranium deposit after McArthur River, also located in the Athabasca Basin $45 \mathrm{~km}$ to the south-west. The Cigar Lake deposit is classified as unconformity-related because the mineralization is located 410 to $450 \mathrm{~m}$ below the surface at the unconformity between an Archean to Paleoproterozoic basement and the unmetamorphosed Paleo- to Mesoproterozoic sedimentary basin (the Athabasca Basin). The deposit is almost entirely basin-hosted, and the basin in this area is composed of red-bed sandstones and conglomerates. The basin has been greatly eroded since the formation of the deposit, with a possible thickness of up to $5 \mathrm{~km}$ at the time of deposit formation (Pagel, 1975). The Cigar Lake deposit sits directly above a major E-W-oriented basement-hosted graphitic-rich structure called the "Cigar Main conductor", which is considered to be a key structure for the formation of the deposit (Bruneton, 1993; Martz et al., 2017). The deposition of uranium is associated with massive hydrothermal alteration in both basin and basement, dominated by the development of an illite-chlorite clay zone and major desilicification (Bruneton, 1993). Large-scale circulations of $\mathrm{NaCl}$ - and $\mathrm{CaCl}_{2}$-rich basinal brines at the basin-basement interface favoured massive fluid-rock interactions leading to the formation of the hydrothermal alteration and $U$ mineralization (Derome et al., 2005; Mercadier et al., 2010; Richard et al., 2016; Martz et al., 2019a). The Cigar Lake uranium deposit is also marked by the presence in the $\mathrm{U}$ ore of arsenide and sulpharsenide minerals of potential economic importance as by-products: rammelsbergite $\left(\mathrm{NiAs}_{2}\right)$, nickeline $(\mathrm{NiAs})$, maucherite $\left(\mathrm{Ni}_{11} \mathrm{As} \mathrm{s}_{8}\right)$, löllingite $\left(\mathrm{Fe} A s_{2}\right)$, skutterudite (NiAss), gersdorffite (NiAsS) and cobaltite (CoAsS) (Reyx and Rulhmann,1993; Kaczowka; 2017). The overall tonnage is estimated at $11000 \mathrm{t}$ for As, $7200 \mathrm{t}$ for $\mathrm{Ni}$ and $1360 \mathrm{t}$ for Co (Cameco, 2016). Although petrographic observations suggest that $\mathrm{Ni}-\mathrm{Co}-\mathrm{Fe}$ arsenides and sulfarsenides were emplaced into the Cigar Lake deposit after fracturing and brecciation of the primary uraninite (Kaczowka, 2017), neither the age of the Ni-CoAs-S episode nor the origin and type of the mineralizing fluids are known, and the exact conditions and mechanism of emplacement of $\mathrm{Ni}, \mathrm{Co}$, As and $\mathrm{S}$ remain unconstrained.

The Cigar Lake U deposit, like all the unconformity-related $U$ deposits of the Athabasca Basin, is marked by a major post-crystallization alteration of the uranium oxides and associated minerals (clays), leading to remobilization of $U$ and formation of secondary disseminated $U$ ore-bodies (Alexandre and Kyser, 2005; Martz 
et al., 2019b). Such alteration/remobilization resulted in resetting of the apparent isotopic ages, complicating accurate and precise $\mathrm{U}-\mathrm{Pb}$ dating on uranium oxides, but also $\mathrm{K}-\mathrm{Ar}$ or ${ }^{40} \mathrm{Ar} /{ }^{39} \mathrm{Ar}$ dating on clays. Multiple approaches to dating the primary uranium mineralization event in the Cigar Lake deposit have been taken, and the resulting ages lie between $1341 \pm 17$ (U-Pb TIMS analysis of uranium oxide mineral separates, Philippe et al.,1993) and $1461 \pm 47 \mathrm{Ma}( \pm 1 \sigma$, in-situ SIMS U-Pb measurements of pure primary uraninite grains, Fayek et al., 2002). Subsequent fluid alteration episodes recrystallized younger generations of U minerals. Fayek et al. (2002) reported stage $2(1176 \pm 9)$ and stage $3(876 \pm 14 \mathrm{Ma})$ generations of U oxides, and Kaczowka (2017) resolved 3 generations of secondary U oxides at $1270 \pm 10 \mathrm{Ma}, 1163 \pm 25 \mathrm{Ma}$ and $947 \pm 57 \mathrm{Ma}$ using U-Pb dating by LA-ICP-MS. The Rb-Sr isochron method provides an age of $1477 \pm 57 \mathrm{Ma}$ for crystalline illites (Kotzer and Kyser, 1995). Philippe et al. (1993) reported K-Ar ages of $1385 \pm 30$ and $1390 \pm 33$ Ma for the $<2 \mu \mathrm{m}$ fraction of clays from the alteration area of the deposit. An event of $U$ remobilization with crystallization of new $U$ oxides is reported at $320 \mathrm{Ma}$ (Philippe et al., 1993).

\section{Materials and methods}

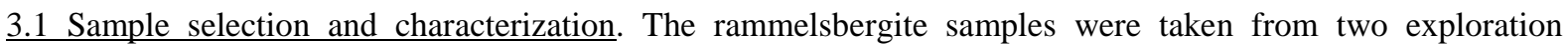
drillholes executed by Areva Resources Canada (currently Orano Canada). Most samples were taken from drillhole WC287 $\left(58.07175^{\circ} \mathrm{N} 104.51813^{\circ} \mathrm{W}\right)$ on the Cigar East mineralized extension of the main body while a single sample was taken from the Cigar North mineralized corridor (WC530; $457.2 \mathrm{~m} ; 58.04123^{\circ} \mathrm{N} 104.33593^{\circ}$ W). The WC287 drillhole first crosscuts fine to medium grained fresh sandstone with rare medium grained grit layers and isolated clay clasts (down to $199.5 \mathrm{~m}$ ), followed by fine to medium grained unaltered sandstone with regular pebbly/gritty intervals before reaching the unconformity with the basement at $424.5 \mathrm{~m}$, underlain by chloritized and argillized graphitic gneiss/pegmatite basement lithologies. The $6.5 \mathrm{~m}$ immediately above the unconformity (418 to $424.5 \mathrm{~m}$ ) are characterised by the presence of high-grade $\mathrm{U}$ mineralization and abundant nickel arsenides. Figure 1 A illustrates massive U oxide vein at $419.1-419.3 \mathrm{~m}$ depth. Massive veins of rammelsbergite are observed between 420.0 and $420.7 \mathrm{~m}$ of the drillhole. The association of massive U oxides and rammelsbergite veins at 419.9-420.1 $\mathrm{m}$ is shown in Figure $1 \mathrm{~B}$. Three different samples from these massive veins of rammelsbergite were taken at the levels of 420.0, 420.1 and 420.7 meters, as shown in Figure 1 A,B,C. No disseminated arsenides were examined in this study. The sample from WC530 was taken from a $2.5 \mathrm{~m}$ chloritized and argillized zone (456.2-458.7) above the unconformity $(458.7 \mathrm{~m})$, characterized by medium uranium grade and abundant nickel arsenides. This zone is underlain by chloritized and argillized graphitic gneiss/pegmatite basement lithologies. The petrography of these rammelsbergite veins is identical to that 
described earlier by Reyx and Rulhmann (1993) for the historical drillholes of Cigar Lake U deposits, as well as by Kaczowka (2017) in a recent study of this deposit.

The drillcores were specifically chosen because they present the most massive and freshest intercepts of rammelsbergite drilled during the last exploration campaigns. Due to its massive character, the rammelsbergite in these veins is easily separable from the uranium oxides and is identical to the rammelsbergite described in the main U mineralization by previous authors for the Cigar Lake U deposit (Reyx and Rulhmann, 1993; Kaczowka, 2017), as well as for other U deposits of the Athabasca Basin (Carl et al., 1992; Annesley et al., 2000; Jefferson et al., 2007; Kyser and Cuney, 2015).

Thick sections were prepared from the samples and were first observed by optical and scanning electron microscopy. The samples are mainly (> 90\%) composed of pure rammelsbergite, a few centimetres thick, contained in a matrix of Mg-Al clays, siderite, uranium oxide and/or calcite (Figure 2A). Small areas of gersdorffite (NiAsS) are occasionally observed at the borders between massive rammelsbergite and the clay/uranium oxide/carbonate matrix. The matrix of the three samples from WC287 also contains disseminated grains of gersdorffite, pyrite (often intergrown with gersdorffite) and chalcopyrite. Massive rammelsbergite from WC530 contains a zone with several 10-100 $\mu \mathrm{m}$ euhedral uranium oxide grains in association with gersdorffite (Figure 3), co-genetic with or closely post-dating the rammelsbergite crystallization. Traces of sparse nickeline (NiAs) are sometimes observed at the edges of the rammelsbergite crystals (Figure 3).

Major and minor element contents of nickel arsenides and sulfarsenides (rammelsbergite and gersdorffite) were measured with a CAMECA SX100 electron microprobe (EMPA) at the Service Commun de Microscopies Electroniques et de Microanalyses of the GeoRessources laboratory (Vandoeuvre-lès-Nancy, France). A set of $\mathrm{Co}, \mathrm{Ni}, \mathrm{Bi}, \mathrm{Cu}$ metal, and pyrite $(\mathrm{FeS} 2)$, molybdenite $\left(\mathrm{MoS}_{2}\right)$, clausthalite $(\mathrm{PbSe})$, stibnite $\left(\mathrm{Sb}_{2} \mathrm{~S}_{3}\right)$ and gallium arsenide (GaAs) mineral standards was used, together with measurement parameters of $20 \mathrm{nA}$ beam current and $20 \mathrm{kV}$ accelerating voltage with a beam diameter of $1 \mu \mathrm{m}$. In spot analysis mode, the intensities of 10 elements were acquired at $\mathrm{K}_{\alpha}$ lines of $\mathrm{S}, \mathrm{Fe}, \mathrm{Co}, \mathrm{Ni}$, and $\mathrm{Cu}, \mathrm{L}_{\alpha}$ lines of $\mathrm{As}, \mathrm{Se}, \mathrm{Sb}$ and $\mathrm{Mo}$, and $\mathrm{M}_{\beta}$ line of $\mathrm{Bi}$, with a $10 \mathrm{~s}$ on-peak acquisition time. An on-peak acquisition time of $200 \mathrm{~ms}$ and spacing of $2-8 \mu \mathrm{m}$ (depending on total mapped area, to limit the total mapping time) was used in mapping mode for $\mathrm{Ni}, \mathrm{As}, \mathrm{Co}, \mathrm{S}$ and Se. BSE images in high-contrast mode were taken using the CAMECA SX100 electron microprobe during the same analytical session. Two-dimensional element distribution maps of the entire thick sections of the samples from 420.1 and 420.7 m depth levels (drillhole WC287) were acquired using a Bruker M4 Tornado XRF instrument at the 
GeoRessources laboratory (Figure 2A), equipped with a 30W Rh- anode X-ray source (50 kV operating voltage, $150 \mu \mathrm{A}$ operating current) and a Be side-window. In this instrument, the X-rays are focused to a $25 \mu \mathrm{m}$ spot (measured for Mo $\mathrm{K}_{\alpha}$ ) using a polycapillary lens. The instrument is equipped with two silicon drift detector spectrometers $\left(30 \mathrm{~mm}^{2}, 145 \mathrm{eV}\right.$ energy resolution for $\left.\mathrm{Mn} \mathrm{K}_{\alpha}\right)$, placed symmetrically relative to the sample. Measurements were performed under a vacuum of 20 mbar.

Rammelsbergite chips of 100-250 mg for Re-Os analysis were cut using a diamond wire saw from the massive vein samples of the WC530 core at $457.2 \mathrm{~m}$ and of the WC287 cores at $420.0 \mathrm{~m}, 420.1 \mathrm{~m}$ and $420.7 \mathrm{~m}$ and are referred to respectively as WC530 and WC287 (420.0), each composed of a single $200 \mathrm{mg}$ sub-sample; WC287 (420.1) A-F (six sub-samples); and WC287 (420.7) A-E (five sub-samples). Prior to acid digestion, the purity of representative rammelsbergite samples and the absence of any potential inclusions of other minerals (silicate, sufides, etc.) and/or alteration phases were verified by observing their virtual 3D models (Fig. 2B) obtained by Xray microtomography using the CT-Scan Nanotom S Phoenix (GE) equipment of the X-ray tomography platform, UMR 7359 GeoRessources Laboratory (Vandoeuvre-lès-Nancy, France). This instrument is equipped with a 180 $\mathrm{kV}$ micro-focus X-ray tube/generator and Flat CMOS $5 \mathrm{Mpx}$ system which enables high-definition X-ray projections. About 1500 projections of rammelsbergite samples were made, using parameters of $98 \mathrm{kV}$ tension, $98 \mu \mathrm{A}$ current, time exposure of $1000 \mathrm{~ms}$, and about $200 \mathrm{~mm}$ distance to the X-ray source detector, with the latter parameter adjusted to obtain the best resolution to size ratio. The spatial resolution varies according to the sample size.

3.2 U-Pb SIMS analysis. The U/Pb and $\mathrm{Pb} / \mathrm{Pb}$ isotopic compositions of the uranium oxide grains in the WC530 sample were measured with a CAMECA IMS 1280 HR2 ion microprobe at the Centre de Recherches Pétrographiques et Géochimiques (CRPG-Nancy, France). The conditions for data acquisition and the isotope data processing protocols are identical to those described in Martz et al. (2019b) and references therein.

3.3 Re-Os reference materials and spikes. National Institute of Standards and Technology (NIST, USA) reference material 8599 Henderson molybdenite was used for quality control of Re and Os analysis and the model age measured (Markey et al., 2007). Isotope spikes of ${ }^{185} \operatorname{Re}(\omega=96.73 \%)$ and ${ }^{190} \mathrm{Os}(\omega=96.99 \%)$ were obtained from Oak Ridge National Laboratory (Tennessee, USA) and mixed at concentrations of $4.7210^{-2} \mathrm{nmol} \mathrm{g}^{-1}{ }^{190} \mathrm{Os}$ and $1.72 \mathrm{nmol} \mathrm{g}^{-1}{ }^{185} \mathrm{Re}$ in high-purity $6 \mathrm{~N} \mathrm{HCl}$ (Le Mignot et al., 2017).

3.4 Sample preparation and digestion protocols for Re-Os dating. All Re-Os isolation and measurements were carried out at the Centre de Recherches Pétrographiques et Géochimiques (CRPG) Nancy, France, under clean 

bulk vein material cannot be crushed or powdered to a mesh size needed for homogenization using traditional approaches. The samples were thus digested in the form of 50-250 $\mu \mathrm{g}$ fragments of pure rammelsbergite, after addition of weighed amounts of ${ }^{185} \mathrm{Re}-{ }^{190} \mathrm{Os}$ mixed isotope tracer (spike). Rammelsbergite appears to passivate in concentrated $\mathrm{HCl}$, but dissolves in $\mathrm{HCl}-\mathrm{HNO}_{3}$ mixtures. Thus to dissolve the rammelsbergite, $8 \mathrm{ml}$ reversed aqua regia $\left(6 \mathrm{ml} 14 \mathrm{M} \mathrm{HNO}_{3}\right.$ and $\left.2 \mathrm{ml} 12 \mathrm{M} \mathrm{HCl}\right)$ were added to the spiked rammelsbergite in $60 \mathrm{ml}$ pre-cleaned quartz digestion vials. Several minutes were allowed before sealing the quartz vials as a precaution against potential vigorous dissolution. Although neither an instant effervescent reaction nor heating in the reversed $a q u a$ regia was observed, minor loss of $\mathrm{Os}$ as $\mathrm{OsO}_{4}$ at this stage cannot be fully excluded, potentially leading to scatter of the ${ }^{187}$ Os concentrations measured if this occurs prior to spike-sample equilibration. Though the absence of heating (and the consistency of the results, see below) suggests that this effect was minor to negligible, cooling the digestion vials during the process of adding the acid to the sample-spike mixtures might be a potential improvement of the analytical procedure to minimize any potential loss of Os. Just before sealing the vials $0.1 \mathrm{ml}$ of $\mathrm{H}_{2} \mathrm{O}_{2}$ were added to assure full oxidation. The sealed vials were then placed in a High-Pressure Asher HPA-S (Anton Paar, Austria) and heated at $280{ }^{\circ} \mathrm{C}$ and a pressure of 100 bars for 6 hours. This procedure not only permitted digestion of the samples, but also brought all of the Os to its highest oxidation state, essential to assure spike-sample equilibration. protocols were modified from Birck et al. (1997). After acid digestion, Os was selectively separated from the sample solution using solvent extraction into liquid bromine, while Re remained in the reversed aqua regia. After addition of $\mathrm{HBr}$ to promote $\mathrm{Os}$ reduction, the $\mathrm{Br}_{2}$ fraction was evaporated, and the Os was further purified by micro-distillation. Os isotopic compositions of the rammelsbergite samples, molybdenite standards and blanks were measured by negative thermal ionization mass spectrometry (N-TIMS; Creaser et al., 1991; Völkening et al., 1991). For this the purified Os concentrated in 1-2 $\mu 1$ of $\mathrm{HBr}$ was loaded onto Re-free Pt filaments with $\mathrm{Ba}(\mathrm{OH})_{2}-\mathrm{NaOH}$ as an emission activator. Isotope ratios of Os were measured as $\mathrm{OsO}_{3}^{-}$ions in CRPG Nancy using a FinniganMAT 262 mass spectrometer operated in single-collection peak jumping mode using an ETP electron multiplier. An oxygen leak valve was used to maintain a source pressure of $3-5 \cdot 10^{-7} \mathrm{mbar}$. The isotope ratios of Os are corrected off-line for heavy oxide, mass fractionation, common Os, and blank contributions, allowing calculation of ${ }^{187}$ Os concentrations by isotope dilution. Instrumental mass fractionation was corrected iteratively simultaneously with the oxide contribution, assuming that the true ${ }^{192} \mathrm{Os} /{ }^{188} \mathrm{Os}$ ratio of the spiked sample 
lies on a mixing line between the natural $\left({ }^{192} \mathrm{Os} /{ }^{188} \mathrm{Os}=3.08271\right)$ and the spike $\left({ }^{192} \mathrm{Os} /{ }^{188} \mathrm{Os}=5.00736\right)$ composition. Radiogenic Os $\left({ }^{187} \mathrm{Os}^{*}\right)$ was corrected for a contribution of common Os, assuming a ${ }^{187}$ Os/ ${ }^{188}$ Os ratio of $0.5 \pm 0.4$, and the uncertainty on this ratio is included in the combined uncertainty on ${ }^{187}{ }^{\circ{ }^{*}}$. The ${ }^{187} \operatorname{Re}$ decay constant $\left(\lambda^{187} \mathrm{Re}\right)$ used for the age calculation is $1.66610^{-11} \mathrm{a}^{-1}$ (Smoliar et al., 1996).

Re was separated from the residual acidic solution remaining after Os extraction into liquid bromine. This solution was evaporated to dryness and re-dissolved in $0.4 \mathrm{M} \mathrm{HNO}_{3}$. Re was extracted from the sample matrix by a simple anion exchange technique using 200-400 mesh AG1X8 resin (BioRad, USA). Re was adsorbed onto 0.6 ml resin in the $0.4 \mathrm{M} \mathrm{HNO}_{3}$ media, the matrix was eluted using $0.8 \mathrm{M} \mathrm{HNO}_{3}$, and after that Re was collected with $8 \mathrm{M}$ $\mathrm{HNO}_{3}$. Measurements of ${ }^{187} \mathrm{Re} /{ }^{185} \mathrm{Re}$ ratios for isotope dilution calculations in rammelsbergite, the Henderson molybdenite reference material and blanks were carried out using an XSeriesII (Thermo Scientific, USA) quadrupole-based ICP-MS unit. Instrumental mass fractionation was corrected for with a sample-standard bracketing approach using a Re standard solution of natural isotopic composition (taken as ${ }^{187} \operatorname{Re} /{ }^{185} \operatorname{Re}=1.6738$ ).

Total procedural blanks were 0.08 - 3 pg for radiogenic ${ }^{187} \mathrm{Os}^{*}$ and $0.01-0.5 \mathrm{ng}$ for Re, representing less than $1 \%$ compared with the quantities of ${ }^{187} \mathrm{Os}(0.47-5.6 \mathrm{ng})$ and $\operatorname{Re}(35-430 \mathrm{ng})$ analysed in the rammelsbergite samples (Table 2). The isotope data are corrected for the blank contribution, and the uncertainty on the blank contribution is included in the total combined uncertainty. These blank values are considerably higher than those typically encountered for non-radiogenic samples in the CRPG laboratory, arguing for some limited cross-contamination between these highly radiogenic, Re-rich samples. Based on repeated measurements of the instrumental blanks before and after every analytical session, it can be concluded that the major part of the Os blank is a result of memory effects within the source of the TIMS instrument, a consequence of high amounts of radiogenic Os found in the samples. Two analyses of the Henderson molybdenite reference material (NIST 8599) were performed, yielding ages of $28.21 \pm 0.34 \mathrm{Ma}$ and $27.98 \pm 031 \mathrm{Ma}$, which are $0.5-0.8 \%$ higher than that given in the detailed characterization of the Henderson reference material by Markey et al. (2007) (27.656 $\pm 0.022 \mathrm{Ma}$, 95\% confidence interval). This could mean that the ages of the rammelsbergite obtained in our study are about 0.5 - $0.8 \%$ (i.e., $10 \mathrm{My}$ ) too high, but this will not change the relative ages of the various sample aliquots.

\section{Results}

4.1. $\mu$ XRF, $\mu$-tomography and EMPA results. Micro XRF 2D mapping of the entire $2.5 \mathrm{~cm}$ epoxy mounts with the embedded WC287 samples from the 420.1 and $420.7 \mathrm{~m}$ depth levels (Figure 2A) reveals inhomogeneous chemical areas within the rammelsbergite veins. These elemental variations are related to changes in the $\mathrm{Co} / \mathrm{Ni}$ 
ratio within the rammelsbergite, as also observed using BSE and element mapping modes of EMPA (Figure 4).

The cobalt content varies mostly between 0.88 and $1.72 \mathrm{wt} . \%$ Co, with one exceptional analysis at $4.85 \mathrm{wt} . \%$ Co for WC287 420.1 and between 0.26 and 1.02 wt.\% for WC287 420.7 (Table 1). The studied arsenides have low average Co $(1.53 \pm 1.2 \mathrm{wt} \%$ for WC287 420.1 and $0.64 \pm 0.27 \mathrm{wt} \%$ for WC287 420.7) and $\mathrm{Fe}(<0.08 \mathrm{wt} \%)$ contents, classifying them as rammelsbergite (see Table 1). Different fragments prepared for Re-Os analysis of rammelsbergite veins from the WC287 drill hole were separately analysed by micro X-ray tomography to characterize their homogeneity in 3D (Fig. 2B and the electronic supplementary materials). These fragments are homogeneous without any detectable inclusions of sulphides, other arsenides or other phases (silicates, carbonates) and do not show any trace of alteration, as demonstrated by the comparison with a fragment of rammelsbergite from drill hole CIG 259-1 (Cigar Lake U deposit, Fig. 2B). This impure fragment displays inclusions of gersdorffite (NiAsS), silicate matrix, and areas of co-existing rammelsbergite and gersdorffite easily detectable by micro X-ray tomography cross-section analysis.

4.2 U-Pb isotope data on the $\mathrm{U}$ oxides. The results of the $\mathrm{U}-\mathrm{Pb}$ and $\mathrm{Pb}-\mathrm{Pb}$ SIMS measurements of the $\mathrm{U}$ oxides embedded in the WC530 massive rammelsbergite vein (Fig. 3) are presented in Figure 5. An upper intercept discordia age of $1255 \pm 71 \mathrm{Ma}(\mathrm{n}=15, \mathrm{MSWD}=12)$ was calculated using model 1 of Ludwig's Isoplot 3.7 (York, 1966; Ludwig, 2008). All analyses display variable degrees of discordancy, indicating post-crystallization alteration as visible in Figure 3B. The discordia is interpreted to represent the age of crystallization of the uranium crystals at $1255 \mathrm{Ma}$, followed by a lead loss event at $242 \mathrm{Ma}$ (calculated age for the lower intercept).

4.3 Re-Os isotope data. The results of ID-NTIMS Os measurements and ID-ICP-MS measurements of Re are presented in Table 2. Rammelsbergite contains high and variable amounts of Re, ranging from $63 \mathrm{ng} \mathrm{g}^{-1}$ to $1.6 \mu \mathrm{g}$ $\mathrm{g}^{-1}$. The Os in rammelsbergite samples consists almost entirely of radiogenic ${ }^{187} \mathrm{Os}$, ranging from 0.8 to $22 \mathrm{ng} \mathrm{g}^{-1}$, while having minimal common Os (9 to $42 \mathrm{pg} \mathrm{g}^{-1}$ of ${ }^{188} \mathrm{Os}$, equivalent to ${ }^{187} \mathrm{Os} /{ }^{188} \mathrm{Os}$ ratios of $94-3442$ ). the 13 chips prepared from the 4 rammelsbergite samples (WC530, WC287420, WC287420.1 and WC287 420.7). The data plotted in a conventional ${ }^{187} \mathrm{Os} /{ }^{188} \mathrm{Os}$ vs. ${ }^{187} \mathrm{Re} /{ }^{188} \mathrm{Os}$ isochron diagram are presented in figure 6B. As these two approaches provide nearly identical ages, while the latter is associated with large propagated uncertainties due to low ${ }^{188} \mathrm{Os}$ abundance and high blank contribution for this isotope, we only discuss the results calculated with ${ }^{187} \mathrm{Os}^{*}-{ }^{187} \mathrm{Re}$ diagram hereafter. This is in line with recommendation of Stein et al. 
309

310

311

312

313

314

315

316

317

318

319

320

321

322

323

324

325

326

327

328

329

330

331

332

333

334

335

336

337

interpreted as an isochron, yields a crystallization age for the rammelsbergite of $1267 \pm 33$ Ma (2 sigma), calculated using York’s regression, implemented as model 1 of Ludwig’s Isoplot 3.7 (York, 1966; Ludwig, 2008). The scatter however greatly exceeds the levels that can be accounted for solely by the assigned analytical uncertainties, as the Mean Square of Weighted Deviation (MSWD) is equal to 138. Because the linearized probability plot for Re-Os model ages suggests that a normal distribution is questionable, the dataset was evaluated for the potential presence of outliers, using the generalized extreme Studentized many-outlier test (GESO test, Rosner, 1983). The test indicates that the rammelsbergite sub-sample «WC287 (420.7m) B», with a model age of 1347.6 \pm 5.2 Ma, may be considered an outlier $\left(\mathrm{G}=2.608>\mathrm{G}_{\text {crit }}=2.462\right)$ at the $95 \%$ confidence level. Treating the «WC287 (420.7m) B» datapoint as an outlier and recalculating a York regression for the data set of 12 points yields an age of $1252 \pm 16$ Ma with a smaller MSWD $=30$.

However, at elevated levels of scatter, the assumption made in the isochron line-fitting algorithm of York's regression (York, 1966) that the weighing factors should be inversely proportional to the analytical uncertainties, is unlikely to be valid (Ludwig, 2008). Although assuming one datapoint as an outlier decreases the MSWD from 138 to 30 , this value is still quite large, suggesting that York's algorithm is not an appropriate choice for line fitting in this case. In situations of elevated scatter, with MSWD >> 1, such as observed for the rammelsbergite, it is preferable to use a line fitting model free of arbitrary assumptions concerning the nature of the scatter, such as that provided by the "robust regression" option in Isoplot 3.70 (Ludwig, 2008). This algorithm calculates the slope as the median of all pairwise slopes (Theil, 1992), with errors calculated according to Rock and Duffy (1986) after Vugrinovich (1981). Using the "robust regression" option on 13 points provides a rammelsbergite emplacement age of $1237+34 /-24$ Ma. If the WC287 (420.7m) B datapoint is excluded from the solution as an outlier, a very similar estimate of $1239+33 /-20$ Ma is obtained. The model ages calculated for the 12 individual samples, presented in Table 2 and as a histogram in Figure 6, result in an average of $1257 \pm 43$ Ma and median of 1257.2, once the result of WC287 $420.7 \mathrm{~B}$ is cancelled as an outlier.

When sub-samples of the WC287 rammelsbergite are evaluated for each of the 420.1 and 420.7 sampling depths individually, the robust regression solution yields $1250+650 /-150$ Ma for 420.7 and 1200 +78/-78 Ma for 420.1 sub-samples (solutions on 5 and 6 points respectively, no outliers confirmed using the GESO test).

\section{Discussion}

5.1 Applicability of Re-Os geochronology to rammelsbergite. This work presents, to our knowledge, the first application of the ${ }^{187} \mathrm{Re}^{-187} \mathrm{Os}$ chronometer to rammelsbergite $\left(\mathrm{NiAs}_{2}\right)$, and one of the few attempts to date 
arsenides using this system. Concerning the other arsenide minerals, ${ }^{187} \mathrm{Re}^{-187} \mathrm{Os}$ system was previously used to date löllingite ( $\mathrm{FeAs}_{2}$ ) by Saintilan et al. (2017), arsenopyrite (FeAsS) by Arne et al. (2001) and Morelli et al. (2005, 2007), and Co-arsenopyrite by Mikulski et al. (2005). The rammelsbergite from the Cigar Lake U deposit is specifically characterised by elevated and variable Re contents, up to nearly $2 \mu \mathrm{g} \mathrm{g}^{-1}$, and very little common Os (up to $0.04 \mathrm{ng} \mathrm{g}^{-1}$ of ${ }^{188} \mathrm{Os}$, see Table 2). The low abundance of common non-radiogenic Os, the large relative amounts of Re and its variable concentrations (Table 2) make rammelsbergite an excellent target for ${ }^{187} \mathrm{Re}^{-187} \mathrm{Os}$ dating. Compared to the other tested arsenide minerals, rammelsbergite is more suitable for ${ }^{187}{ }^{12}-{ }^{187}$ Os dating than e.g. arsenopyrite or löllingite, which can contain large amounts of common Os (e.g. löllingite from the Broken Hill $\mathrm{Pb}-\mathrm{Zn}-\mathrm{Ag}$ deposit in Australia contains up to $\sim 26 \mathrm{ng} \mathrm{g}^{-1}$ of ${ }^{188} \mathrm{Os}$, calculated from data in Saintilan et al. (2017)) or be characterized by relatively low levels of parent Re (below $12 \mathrm{ng} \mathrm{g}^{-1}$ ); Arne et al. (2001) and Morelli et al. $(2005,2007))$. We suggest that crystal lattice constraints of the rammelsbergite allow it to preferentially concentrate Re rather than Os during crystallization, leading over time to the accumulation of radiogenic ${ }^{187} \mathrm{Os}^{*}$ in quantities sufficient for high-precision isotopic analysis. In this respect rammelsbergite is analogous to molybdenite, the most widely used phase in Re-Os geochronometry (Stein et al., 2001). The U oxide grains found in the WC530 massive rammelsbergite (Figure 3) are crystallized within the rammelsbergite, without clear relationship to specific fractures cross-cutting the rammelsbergite. These euhedral crystals of uranium oxide can be thus considered as co-genetic to the crystallization of the rammelsbergite, suggesting that the two phases crystallized during the same fluid circulation event. As such, the $1255 \pm 71 \mathrm{Ma}$ U-Pb upper intercept discordia age (Figure 5) defined for these $\mathrm{U}$ oxides can be interpreted as the oldest temporal constraint for the rammelsbergite at the Cigar Lake U deposit. The fact that the U-Pb SIMS age coincides within error with the 1254 $\pm 12 \mathrm{Ma}$ model age for the fragment of WC530 (Table 2) and with the Re-Os $1239+33 /-20 \mathrm{Ma}$ isochron age calculated for the Cigar Lake rammelsbergite confirms the suitability of the Re-Os radioisotope decay couple for rammelsbergite dating. It also confirms that the rammelsbergite Re-Os isotope data array is not an accidental mixing line between two components.

The isotopic data for rammelsbergite plot very close to a straight line in ${ }^{187} \mathrm{Os}-{ }^{187} \mathrm{Re}$ space (Figure 6) whereas several hydrothermal fluid circulation events occurred in the Cigar Lake U deposits after the crystallization of the rammelsbergite (ca. $1170 \mathrm{Ma}$, ca. $900 \mathrm{Ma}$, ca. $320 \mathrm{Ma}$, ca. $250 \mathrm{Ma}$ and ca. $40 \mathrm{Ma}$ ) and perturbed the isotopic systems of both uranium oxides (e.g. at 242 Ma, see Figure 5 and Martz et al., 2019b) and clays (Fayek et al., 2002; Kaczowka, 2017; Philippe et al., 1993). Such linearity indicates the resistance of rammelsbergite to gain or loss of Re or incorporation of common Os and/or radiogenic Os loss after its initial crystallization. Tests now need 
to be done on rammelsbergite from other types of deposits, from the Athabasca Basin and elsewhere, including those formed under different conditions to confirm the global applicability of the Re-Os isotopic system for dating of this mineral and related $\mathrm{Ni}$ mineralization.

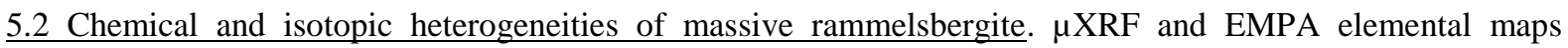
demonstrate that the tested rammelsbergite veins include intermixtures of domains with variable Co contents (Figures 2 and 4; table 1). The variability of the Re content measured in the different chips of rammelsbergite may be linked to this heterogeneity of the $\mathrm{Co} / \mathrm{Ni}$ ratio within the massive rammelsbergite veins. The variable concentration of Re in the rammelsbergite at the time of crystallization is a key point for ${ }^{187} \mathrm{Re}^{187} \mathrm{Os}$ dating of this phase, allowing for construction of single-mineral ${ }^{187} \mathrm{Re}-{ }^{187} \mathrm{Os}$ isochrons as is classically done for molybdenite (Stein et al., 2000). The origin of these chemical variations is not currently known. This fine-scale heterogeneity of the massive rammelsbergite might be related to a subsolidus process occuring during slow cooling after the initial precipitation of the rammelsbergite, before sub-solidus diffusion is effectively closed. Alternatively, the structure of Co-rich and Co-poor domains of the rammelsbergite might develop during post-depositional thermal reequilibration events younger than $1239+33 /-20 \mathrm{Ma}$, such as that responsible for formation of stage 3 at 876 947 Ma (Fayek et al., 2002; Kaczowka, 2017) or ca. 350 Ma (Philippe et al., 1993) uranium oxides for example. While both cases could contribute to the scatter in the ${ }^{187} \mathrm{Re}-{ }^{187} \mathrm{Os}$ isotope systematics, the effect of Re-Os redistribution in the latter case would be expected to be much stronger, since the events occurred several hundred millions of years after rammelsbergite crystallization, after substantial amounts of ${ }^{187}$ Os have had the chance to grow in. Such a process would not produce the obtained isochron. Thus, the protracted cooling period after the initial precipitation of rammelsbergite linked to subsolidus equilibration of Re and Co-Ni seems a much more likely explanation. A third possibility could be that the heterogeneous $\mathrm{Co} / \mathrm{Ni}$ composition of massive rammelsbergite results from growth under changing conditions, at varying temperature, fluid compositions, and/or activities of $\mathrm{Co}$ and Ni. Common Os of variable isotopic composition could be incorporated into the nickel arsenide during this process, which could contribute to the scatter of the isochron. During our analytical procedure, common Os was measured and is later corrected for assuming a ${ }^{187} \mathrm{Os} /{ }^{188} \mathrm{Os}$ ratio of $0.5 \pm 0.4$. However, if common Os with more radiogenic and/or more variable composition is incorporated into the sub-samples during crystallization of rammelsbergite, this would not be accounted for, and could introduce scatter. However, the fact that the $y$-intercept of the isochron in Figure 6 plots well within error of zero suggests that underestimation of the initial radiogenic Os component was not a generalized problem. 
397

398

399

400

401

402

403

404

405

406

407

408

409

410

411

412

413

414

415

416

417

418

419

420

421

422

423

424

425

Finally, some of the scatter in the isochron diagram could result from the fact that Re and ${ }^{187} \mathrm{Os}$ may not enter into the same structural sites in the crystal, resulting in spatial decoupling. This possibility was summarized for molybdenite in Stein and Hannah (2014). As shown by Takahashi et al. (2007), ${ }^{187}$ Os has a smaller radius and a lower valence than Re incorporated in the molybdenite structure, suggesting that newly formed radiogenic Os could diffuse more rapidly than Re and thus is more likely to enter into structural defects. It is possible that a similar process could cause spatial decoupling of radiogenic Os from its parent Re in the rammelsbergite. Radiogenic Os may have diffused out of (or into) the small sub-sample over time into more favourable sites in the surrounding crystal, thus leading to the scatter observed.

These different possibilities of scatter need to be constrained, but the first results on rammelsbergite clearly demonstrate that this mineral presents a high potential for use in Re-Os geochronometry. The diversity of geological contexts in which rammelsbergite can be found, from magmatic to hydrothermal conditions, and its possible future significance as a source of nickel, could allow a rapid development of its use to constrain geological models, as demonstrated below for the unconformity-related $\mathrm{U}$ deposits. In this context rammelsbergite could complement molybdenite as dating targets in deposit environments where molybdenite is not common.

5.3 Contribution of rammelsbergite Re-Os dating to the formation model for unconformity-related U deposits.

The best estimate for the age of emplacement of rammelsbergite in the Cigar Lake uranium deposit is $1239+33 /-$ $20 \mathrm{Ma}$ (robust regression solution on 12 points, excluding sample WC287 (420.7m) B, figure 6). This age is the first obtained on sulphides, sulpharsenides or arsenides for the unconformity-related $U$ deposits of the Athabasca Basin. It provides new key information about the formation of unconformity-related $U$ deposits and fills several important gaps in our understanding of the genetic model of these world-class deposits.

The $1239+33 /-20$ Ma Re-Os age first demonstrates that rammelsbergite crystallized late compared to the earliest generation of uranium oxide. The age of primary deposition of uranium oxides in the Cigar Lake deposit is still debated, due to the susceptibility of the U-Pb system in uranium oxide to disturbance under post-crystallization conditions (Fayek et al., 2000; Alexandre and Kyser, 2005; Macmillan et al., 2016; Martz et al., 2019a), but the 1341 - $1461 \mathrm{Ma}$ age range is commonly interpreted to date the primary $\mathrm{U}$ oxide deposition event (Philippe et al., 1993; Fayek et al., 2002). Numerous U-Pb ages post-dating the first $\mathrm{U}$ deposition have been measured on uranium oxides in the Cigar Lake U deposit, as well as at a broader scale for the different unconformity-related U deposits of the Athabasca Basin. These ages cover a broad period of over a billion years, with different individualized statistical peaks (Cumming and Krstic, 1992; Philippe et al., 1993; Fayek et al., 2002a; Fayek et al., 2002b; 

rammelsbergite, the $\mathrm{U}-\mathrm{Pb}$ ages of secondary uranium oxides within the Athabasca $\mathrm{U}$ province, and the age of the U oxides found within the WC530 rammelsbergite vein (figure 5) likely indicates that primary uranium oxides were strongly hydrothermally remobilized/perturbed during the emplacement of the arsenides, sufides and sulpharsenides in these unconformity-related $\mathrm{U}$ deposits. Temporal distinction between the rammelsbergite and initial $\mathrm{U}$ oxide emplacement observed in this work is also in agreement with recently observed discrepancies in lateral distributions of $\mathrm{U}$ and $\mathrm{Ni}$ in a single pod of the Cigar Lake deposit (c.f. figure 2.21 of Kaczowka, 2017).

Another possibility is that the massive veins of rammelsbergite are secondary and do not represent rammelsbergite disseminated in the $\mathrm{U}$ ores, which might instead be contemporaneous with primary $\mathrm{U}$ mineralization at ca. 1341 - $1461 \mathrm{Ma}$. Though we did not evaluate disseminated Ni arsenides in this study, such phases may have precipitated in the same event as the primary $\mathrm{U}$ oxides but then have been mobilized as primary uranium oxides in a subsequent $1239 \mathrm{Ma}$ event, which reset the ${ }^{187} \mathrm{Re}^{187} \mathrm{Os}$ system and crystallized massive rammelsbergite veins. This scenario is however not supported by the near-zero initial ${ }^{187} \mathrm{Os} /{ }^{188} \mathrm{Os}=0.8 \pm 6.6$ observed for the massive rammelsbergite (Fig. 6B). If the massive rammelsbergite veins were indeed formed by dissolution and remobilization of primary $\mathrm{Ni}$ arsenides, radiogenic initial Os is expected because in the intervening 100-220 Ma period the hypothetical primary $\mathrm{Ni}$ arsenides would acquire significant amounts of ${ }^{187} \mathrm{Os}$ by radiogenic ingrowth. We cannot completely exclude a secondary origin for the massive rammelsbergite, because near-zero initial ${ }^{187} \mathrm{Os} /{ }^{188} \mathrm{Os}$ could conceivably be explained by (i) elevated uncertainty on the intercept as a result of geological scatter, or (ii) an absence of Re in the hypothetical primary Ni arsenides, which would then have been introduced into the system only at $1239 \mathrm{Ma}$, or (iii) a potentially high distribution coefficient for Os in the fluid-mineral system, preventing any radiogenic Os from entering the rammelsbergite lattice. However in the absence of any evidence supporting these suggestions, the contemporaneous emplacement of $\mathrm{U}$ and $\mathrm{Ni}$ arsenides in the Cigar Lake deposit must be viewed as hypothetical.

Despite the elevated uncertainty on the ${ }^{187} \mathrm{Re}^{187} \mathrm{Os}$ age found for Cigar Lake rammelsbergite, our data strongly suggest that the endowment of $\mathrm{Ni}, \mathrm{Co}, \mathrm{S}$ and As in unconformity-related $\mathrm{U}$ deposits of the Athabasca Basin is linked to the Mesoproterozoic magmatic event responsible for the emplacement at $1269 \mathrm{Ma}$ of the Mackenzie large igneous province (LIP) over a vast area of northern Canada and Russia (LeCheminant and Heaman, 1989). The Mackenzie LIP is represented by the mafic-ultramafic layered Muskox intrusion $(1269 \pm 2$ Ma, Mackie et al., 
related giant swarm of Mackenzie diabase dikes (1267 \pm 2 Ma to $1268.5 \pm 1.5 \mathrm{Ma}$, LeCheminant and Heaman, 1989; Schwab et al., 2004), which radiate outwards over at least $2400 \mathrm{~km}$, reaching the Athabasca Basin (Mackie et al., 2009). The focal point of the dike swarm is located approximately $1100 \mathrm{~km}$ north east of the Cigar Lake deposit and several mafic dykes have been described as crosscutting the Athabasca Basin and the U mineralization, for example at the Midwest and Centennial deposits (Alexandre et al., 2012; Reid et al., 2014). Our new ${ }^{187}$ Re${ }^{187}$ Os age of $1239+33 /-20 \mathrm{Ma}$ for the rammelsbergite of the Cigar Lake U deposit demonstrates that nickel arsenide veins in the uranium deposit were either emplaced at the same time as the mafic dikes, or formed several millions to tens of millions of years after their emplacement, by fluid mobilization of elements ( $\mathrm{Ni}, \mathrm{Co}$, As) derived from a probable mafic source. Presumably, the Mackenzie event provided both the material, in the form of Ni-As rich magmas, and potentially the energy needed for hydrothermal activity to transport the metals to the Athabasca Basin, where they are redeposited in the form of arsenides, sulfides and sulfarsenides in the uranium deposits. In this context Ni-Co-As mineral precipitation seems to be dependent on structural controls and reducing environments, likely resulting from hydrogen produced by the radiolysis of water, similar to those that drove earlier U reduction and deposition (Dargent et al., 2015; Truche et al., 2018) because there are no occurrences of Ni-Co-As independent from $\mathrm{U}$ deposits in the Athabasca Basin. The Mackenzie event thus deeply modified the initial characteristics of the unconformity-related $\mathrm{U}$ deposits, being likely responsible for remobilisation of the primary stage 1 uranium oxides in the deposit, with partial to total resetting of the U-Pb uraninite age and formation of stage 2 uranium oxides (as well as the U oxides found within the WC530 rammelsbergite vein), and for massive deposition of nickel, cobalt, sulfur and arsenic in the form of arsenides, sulphides and sulfarsenides. terms of monometallic and polymetallic genetic models, on the basis of associated metals. Polymetallic ores, like that of the Cigar Lake U deposit, are characterized by anomalous concentrations of sulphides, sulpharsenides and arsenides containing significant amounts of $\mathrm{Ni}, \mathrm{Co}, \mathrm{S}, \mathrm{As}, \mathrm{Cu}, \mathrm{Pb}, \mathrm{Zn}$ and $\mathrm{Mo}$, whereas monometallic ores, like that of the McArthur U deposit, contain only traces of metals other than U (Jefferson et al., 2007; Kyser and Cuney, 2015). Such mineralogical differences have been explained until now using two end-member genetic models for the unconformity-related $\mathrm{U}$ deposits in the Athabasca Basin, one for monometallic deposits and one for polymetallic deposits (Hoeve and Sibbald, 1978; Fayek and Kyser, 1997; Quirt, 2003; Jefferson et al., 2007; Kyser and Cuney, 2015). The major differences between these two end-member models is the involvement of a basement-derived reduced fluid to explain both $\mathrm{U}$ deposition and the source of $\mathrm{Ni}, \mathrm{Co}, \mathrm{S}, \mathrm{As}, \mathrm{Cu}$ and $\mathrm{Zn}$ in polymetallic deposits. Such a fluid is not considered to have been involved in monometallic deposits, which 
instead are thought to have formed from oxidized and U-bearing basinal brines flowing into basement-rooted structures and interacting with reduced minerals (Hoeve and Sibbald, 1978; Kotzer and Kyser, 1995; Fayek and Kyser, 1997; Jefferson et al., 2007; Kyser and Cuney, 2015). These two genetic models which have guided the exploration of unconformity-related $\mathrm{U}$ deposits for years are based on the postulate that the $\mathrm{U}, \mathrm{Ni}, \mathrm{Co}, \mathrm{S}$ and $\mathrm{As}$ $( \pm \mathrm{Zn}, \mathrm{Cu})$ are introduced simultaneously into the deposits. The clear differences in the timing of the initial deposition of the uranium and of the Ni-Co in the Athabasca Basin calls for reconsideration of the existing models. Our results suggest that the presence of nickel and cobalt, as well as associated elements such as S and As, in unconformity-related $\mathrm{U}$ deposits is directly linked to the local involvement of mafic dykes of MacKenzie age in the vicinity of some of these $U$ deposits, including the Cigar Lake, Midwest and Centennial deposits. These dykes favoured specific and localized circulations of $\mathrm{Ni}$ - and Co-rich fluids at ca. 1250-1270 Ma leading to crystallization of arsenides, sulphides and sulfarsenides in the reduced environment of the uranium deposits and the perturbation/recrystallization of the uranium oxides. This scenario explains the formation of the polymetallic deposits. The U deposits of the Athabasca Basin in which geological and structural conditions have not allowed the local intrusion of dykes and related fluid circulation at ca. 1250-1270 Ma are not enriched in sulphides, sulfarsenides or arsenides, and have thus remained monometallic.

\section{Summary and conclusions}

502

This work presents the first tests of Re-Os dating on rammelsbergite $\left(\mathrm{NiAs}_{2}\right)$, a rare mineral at a global scale but often present in ore deposits worldwide in association with other arsenides, sulphides and sulfarsenides. This study is one of the first published on the Re-Os dating of arsenides, minerals that may be of future economic interest due to their content in nickel or cobalt. The suitability of the Re-Os chronometer for dating rammelsbergite is demonstrated here for the unconformity-related uranium deposits of the Athabasca Basin (Canada), using the example of the world-class Cigar Lake deposit. The massive rammelsbergite veins found in this deposit display significant (up to $1.7 \mu \mathrm{g} \mathrm{g}^{-1}$ ) and variable Re contents, coupled with a near absence of common Os, making this mineral an ideal candidate for ${ }^{187} \mathrm{Re}^{187} \mathrm{O}$ s dating, by both isochron and model age methods, comparable in this respect to molybdenite. Similarity of the Re-Os age of the rammelsbergite and the U-Pb age of the accessory uranium oxide grains found inside one of the massive rammelsbergite veins confirms the applicability of the method. Furthermore, the Re-Os isotopic system appears to be resistant to post-crystallization perturbation. The ${ }^{187} \mathrm{Re}^{187} \mathrm{Os}$ isotope system applied to rammelsbergites from various economically important ore deposits throughout the world may thus serve as a powerful dating tool. This study demonstrates that the Re-Os 
515 chronometer can be applied to rammelsbergite in ore deposits where molybdenite is rare or absent, and suggests

516 that the pertinence of this system should also be evaluated in other arsenide minerals.

517 For the case of unconformity-related U deposits, rammelsbergite from the Cigar Lake deposit demonstrates the 518 potential of new ${ }^{187} \mathrm{Re}^{-187} \mathrm{Os}$ mineral proxies used in conjunction with traditional chronometers, to challenge long519 established petrogenetic deposit models and to advance our understanding of the distribution of critical mineral 520 resources. The $1239+33 /-20 \mathrm{Ma}$ age calculated for the crystallization of the rammelsbergite in the Cigar Lake uranium deposit provides new first-order constraints on the formation and evolution of unconformity-related U deposits, and argues for a profound reconsideration of existing genetic models. This result first demonstrates that the massive precipitation of arsenides, sulphides and sulpharsenides post-dates the deposition of primary uranium oxides (1341 - $1461 \mathrm{Ma}$ ) and that the endowment of Ni-Co in the Athabasca Basin was disconnected in time from that of $\mathrm{U}$. The similarity between the age of the rammelsbergite and a secondary age peak including many uranium oxides in Athabascan unconformity-related $U$ deposits indicates that the primary uranium oxides were strongly perturbed and/or remobilized when rammelsbergite and related minerals crystallized. The massive emplacement of rammelsbergite is most probably genetically linked to the 1269 Ma Mesoproterozoic magmatic Mackenzie event. Presumably, this event activated regional hydrothermal activity, resulting in partial mobilisation of primary uranium oxides, resetting of the $\mathrm{U}-\mathrm{Pb}$ system in the uraninite, mobilisation of $\mathrm{Ni}$, Co and As from the ultramafic materials, and their precipitation in the deposit adjacent to uranium oxides. In favourable structural contexts this process led to the formation of the so-called "polymetallic deposits" of the Athabasca Basin. This study thus suggests a plausible new mechanism for the emplacement of nickel and cobalt in unconformity-related U deposits and represents a first step towards defining a new genetic model for these world-class deposits.

\section{Acknowledgments}

537 S.Ch. acknowledges his postdoctoral fellowship grant provided by CREGU (Centre de Recherches sur la Géologie des Matières Premières Minérales et Energétiques), a subsidiary of ORANO and TOTAL. The authors thank

539 ORANO for the permission to publish these results, and CAMECO for logistical assistance during the sampling.

540 Christiane Parmentier and Aimeryc Schumacher (CRPG Nancy) are acknowledged for their kind help with the 541 clean laboratory and mass-spectrometry setup. J.M. would like to thank Mathias Burisch (TUB Freiberg) for his help referencing the occurrences of arsenides. The executive editor Jeffrey Catalano, Holly Stein and two 
anonymous reviewers are acknowledged for their useful comments, which helped to improve the quality of this manuscript.

\section{References}

Alexandre P., Kyser K., Jiricka D. and Witt G. (2012) Formation and Evolution of the Centennial Unconformity-Related Uranium Deposit in the South-Central Athabasca Basin, Canada. Econ. Geol. 107, 385-400. Available at: https://pubs.geoscienceworld.org/economicgeology/article/107/3/385-400/128352 [Accessed May 19, 2019].

Alexandre P., Kyser K., Thomas D., Polito P. and Marlat J. (2009) Geochronology of unconformity-related uranium deposits in the Athabasca Basin, Saskatchewan, Canada and their integration in the evolution of the basin. Miner. Depos. 44, 41-59. Available at: http://link.springer.com/10.1007/s00126-007-0153-3 [Accessed May 2, 2019].

Alexandre P. and Kyser T. K. (2005) Effects of cationic substitutions and alteration in uraninite, and implications for the dating of uranium deposits. Can. Mineral. 43, 1005-1017. Available at: http://www.canmin.org/cgi/doi/10.2113/gscanmin.43.3.1005 [Accessed May 2, 2019].

Annesley I. R., Madore C. and Bonli T. (2000) Uraninite-bearing Granitic Pegmatite, Moore Lakes, Saskatchewan: Petrology and U-Th-Pb Chemical Ages. Summ. Investig. Saskatchewan Energy Mines, Saskatchewan Geol. Surv. 2, 201-211.

Annesley I. R., Madore C. and Portella P. (2005) Geology and thermotectonic evolution of the western margin of the Trans-Hudson Orogen: evidence from the eastern sub-Athabasca basement, Saskatchewan. Can. J. Earth Sci. 42, 573-597. Available at: http://www.nrcresearchpress.com/doi/10.1139/e05-034 [Accessed May 18, 2018].

Arne D. C., Bierlin F. P., Morgan J. W. and Stein H. J. (2001) Re-Os dating of sulfides associated with gold mineralization in Central Victoria, Australia. Econ. Geol. 96, 1455-1459. Available at: https://pubs.geoscienceworld.org/economicgeology/article/96/6/1455-1459/22109 [Accessed December 11, 2019].

Bagheri H. (2015) Crustal lineament control on mineralization in the Anarak area of Central Iran. Ore Geol. Rev. 66, 293-308. Available at: http://dx.doi.org/10.1016/j.oregeorev.2014.10.028.

Birck J. L., Barman M. R. and Capmas F. (1997) Re-Os Isotopic Measurements at the Femtomole Level in 
Bortnikova S., Bessonova E. and Gaskova O. (2012) Geochemistry of arsenic and metals in stored tailings of a Co-Ni arsenide-ore, Khovu-Aksy area, Russia. Appl. Geochemistry 27, 2238-2250. Available at: http://dx.doi.org/10.1016/j.apgeochem.2012.02.033.

Bruneton P. (1993) Geological environment of the Cigar Lake uranium deposit. Can. J. Earth Sci. 30, $653-673$. Available at: http://www.nrcresearchpress.com/doi/10.1139/e93-054.

Burisch M., Gerdes A., Walter B. F., Neumann U., Fettel M. and Markl G. (2017) Methane and the origin of five-element veins: Mineralogy, age, fluid inclusion chemistry and ore forming processes in the Odenwald, SW Germany. Ore Geol. Rev. 81, 42-61. Available at: https://www.sciencedirect.com/science/article/pii/S0169136816303675 [Accessed May 8, 2019].

Cameco (2016) Reserves and Resources. Available at: https://www.cameco.com/businesses/uraniumoperations/Canada/cigar-lake/reserves-resources.

Carl C., Pechmann E. von, Höhndorf A. and Ruhrmann G. (1992) Mineralogy and U/Pb, Pb/Pb, and Sm/Nd geochronology of the Key Lake uranium deposit, Athabasca Basin, Saskatchewan, Canada. Can. J. Earth Sci. 29, 879-895. Available at: http://www.nrcresearchpress.com/doi/abs/10.1139/e92-075\#.VN4lzPmGLE.

Changkakoti A. and Morton R. D. (1986) Electron microprobe analyses of native silver and associated arsenides from the Great Bear Lake silver deposits, Northwest Territories, Canada. Can. J. Earth Sci. 23, 14701479. Available at: http://www.nrcresearchpress.com/doi/abs/10.1139/e86-142\#.WwfVXSvKFD9.

Cloutier J., Kyser K., Olivo G. R., Alexandre P. and Halaburda J. (2009) The Millennium Uranium Deposit, Athabasca Basin, Saskatchewan, Canada: An Atypical Basement-Hosted Unconformity-Related Uranium Deposit. Econ. Geol. 104, 815-840. Available at: https://pubs.geoscienceworld.org/economicgeology/article/104/6/815-840/128121 [Accessed May 2, 2019].

Cloutier J., Kyser K., Olivo G. R. and Brisbin D. (2011) Geochemical, isotopic, and geochronlologic constraints on the formation of the Eagle Point basement-hosted uranium deposit, Athabasca Basin, Saskatchewan, Canada and recent remobilization of primary uraninite in secondary structures. Miner. Depos. 46, 35-56. Available at: http://link.springer.com/10.1007/s00126-010-0308-5 [Accessed May 2, 2019]. 
Creaser R. A., Papanastassiou D. A. and Wasserburg G. J. (1991) Negative thermal ion mass spectrometry of osmium, rhenium and iridium. Geochim. Cosmochim. Acta 55, 397-401. Available at: https://www.sciencedirect.com/science/article/pii/0016703791904277 [Accessed May 16, 2018].

Cumming G. L. and Krstic D. (1992) The age of unconformity-related uranium mineralization in the Athabasca Basin, northern Saskatchewan. Can. J. Earth Sci. 29, 1623-1639. Available at: http://www.nrcresearchpress.com/doi/10.1139/e92-128 [Accessed May 2, 2019].

Dargent M., Truche L., Dubessy J., Bessaque G. and Marmier H. (2015) Reduction kinetics of aqueous U(VI) in acidic chloride brines to uraninite by methane, hydrogen or C-graphite under hydrothermal conditions: Implications for the genesis of unconformity-related uranium ore deposits. Geochim. Cosmochim. Acta 167, 11-26. Available at: https://www.sciencedirect.com/science/article/pii/S001670371500410X [Accessed December 11, 2019].

Day J. M. D., Pearson D. G. and Hulbert L. J. (2013) Highly siderophile element behaviour during flood basalt genesis and evidence for melts from intrusive chromitite formation in the Mackenzie large igneous province. Lithos 182-183, 242-258. Available at: http://dx.doi.org/10.1016/j.lithos.2013.10.011.

Deng X.-D., Luo T., Li J.-W. and Hu Z.-C. (2019) Direct dating of hydrothermal tungsten mineralization using in situ wolframite U-Pb chronology by laser ablation ICP-MS. Chem. Geol. 515, 94-104. Available at: https://www.sciencedirect.com/science/article/abs/pii/S0009254119301688 [Accessed May 19, 2019].

Derome D., Cathelineau M., Cuney M., Fabre C., Lhomme T. and Banks D. A. (2005) Mixing of Sodic and Calcic Brines and Uranium Deposition at McArthur River, Saskatchewan, Canada: A Raman and LaserInduced Breakdown Spectroscopic Study of Fluid Inclusions. Econ. Geol. 100, 1529-1545. Available at: https://pubs.geoscienceworld.org/economicgeology/article/100/8/1529-1545/127679 [Accessed April 25, 2019].

Fayek M., Burns P., Guo Y.-X. and Ewing R. C. (2000) Micro-structures associated with uraninite alteration. J. Nucl. Mater. 277, 204-210. Available at: https://www.sciencedirect.com/science/article/pii/S0022311599001993 [Accessed May 2, 2019].

Fayek M., Harrison T. M., Ewing R. C., Grove M. and Coath C. D. (2002a) O and Pb isotopic analyses of uranium minerals by ion microprobe and U-Pb ages from the Cigar Lake deposit. Chem. Geol. 185, 205225.

Fayek M., Kyser T. K. and Riciputi L. R. (2002b) U and Pb isotope analysis of uranium minerals by ion 

microprobe and the geochronology of the McArthur river and Sue Zone uranium deposits, Saskatchewan, Canada. Can. Mineral. 40, 1553-1570. Available at: http://www.canmin.org/cgi/doi/10.2113/gscanmin.40.6.1553 [Accessed May 2, 2019].

Forster H.-J., Rhede D. and Tischendorf G. (2004) Mineralogy of the Niederschlema Alberoda U Se polymetallic deposit, Erzgebirge, Germany. I. Jolliffeite, NiAsSe, the rare Se-dominant analogue of gersdorffite. Can. Mineral. 42, 841-849. Available at: http://www.canmin.org/cgi/doi/10.2113/gscanmin.42.3.841.

Fryer B. J. and Taylor R. P. (1984) Sm-Nd direct dating of the Collins Bay hydrothermal uranium deposit, Saskatchewan. Geology 12, 479-482. Available at: http://geology.gsapubs.org/content/12/8/479.short.

Gritsenko Y. D. and Spiridonov E. M. (2008) Maucherite from metamorphic-hydrothermal assemblages of the Noril'sk ore field. Geol. Ore Depos. 50, 590-598. Available at: http://link.springer.com/10.1134/S1075701508070106.

Harlaux M., Romer R. L., Mercadier J., Morlot C., Marignac C. and Cuney M. (2018) 40 Ma of hydrothermal W mineralization during the Variscan orogenic evolution of the French Massif Central revealed by $\mathrm{U}-\mathrm{Pb}$ dating of wolframite. Miner. Depos. 53, 21-51. Available at: http://link.springer.com/10.1007/s00126017-0721-0 [Accessed April 25, 2019].

Jefferson C. W., Thomas D. J., Gandhi S. S., Ramaekers P., Delaney G., Brisbin D., Cutts C., Quirt D., Portella P. and Olson R. A. (2007) Unconformity-associated uranium deposits of the Athabasca Basin, Saskatchewan and Alberta. In EXTECH IV: Geology and Uranium Exploration Technology of the Protoproterozoic Athabasca Basin, Saskatchewan and Alberta (eds. C. W. Jefferson and G. Delaney). Geological Survey of Canada Bulletin. pp. 23-67.

Kaczowka A. J. (2017) Geometallurgical and geological evaluation of the high-grade polymetallic unconformity-related Cigar Lake uranium deposit. Queen's University Kingston, Ontario, Canada.

Kotzer T. G. and Kyser T. K. (1995) Petrogenesis of the Proterozoic Athabasca Basin, northern Saskatchewan, Canada, and its relation to diagenesis, hydrothermal uranium mineralization and paleohydrogeology. Chem. Geol. 120, 45-89. Available at: https://www.sciencedirect.com/science/article/pii/000925419400114N [Accessed May 18, 2018].

Kyser K. and Cuney M. (2015) The Geology and Geochemistry of Uranium and Thorium Deposits., Mineralogical Association of Canada, Montreal. 
LeCheminant A. N. and Heaman L. M. (1989) Mackenzie igneous events, Canada: Middle Proterozoic hotspot magmatism associated with ocean opening. Earth Planet. Sci. Lett. 96, 38-48.

Legros H., Mercadier J., Villeneuve J., Romer R. L., Deloule E., Van Lichtervelde M., Dewaele S., Lach P., Che X.-D., Wang R.-C., Zhu Z.-Y., Gloaguen E. and Melleton J. (2019) U-Pb isotopic dating of columbitetantalite minerals: Development of reference materials and in situ applications by ion microprobe. Chem. Geol. 512, 69-84. Available at: https://www.sciencedirect.com/science/article/abs/pii/S0009254119300993 [Accessed May 19, 2019].

Ludwig K. R. (2008) User's manual for Isoplot 3.70. Berkeley Geochronol. Cent. Spec. Publ. No.4.

Mackie R. A., Scoates J. S. and Weis D. (2009) Age and Nd-Hf isotopic constraints on the origin of marginal rocks from the Muskox layered intrusion (Nunavut, Canada) and implications for the evolution of the 1.27 Ga Mackenzie large igneous province. Precambrian Res. 172, 46-66.

Macmillan E., Ciobanu C. L., Ehrig K., Cook N. J. and Pring A. (2016) Chemical zoning and lattice distortion in uraninite from Olympic Dam, South Australia. Am. Mineral. 101, 2351-2354. Available at: https://pubs.geoscienceworld.org/ammin/article/101/10/2351-2354/298305.

Markey R., Stein H. J., Hannah J. L., Zimmerman A., Selby D. and Creaser R. A. (2007) Standardizing Re-Os geochronology: A new molybdenite Reference Material (Henderson, USA) and the stoichiometry of Os salts. Chem. Geol. 244, 74-87. Available at: https://www.sciencedirect.com/science/article/pii/S0009254107002513 [Accessed August 7, 2018].

Martz P., Cathelineau M., Mercadier J., Boiron M. C., Jaguin J., Tarantola A., Demacon M., Gerbeaud O., Quirt D., Doney A. and Ledru P. (2017) C-O-H-N fluids circulations and graphite precipitation in reactivated Hudsonian shear zones during basement uplift of the Wollaston-Mudjatik Transition Zone: Example of the Cigar Lake U deposit. Lithos 294-295, 222-245. Available at: http://dx.doi.org/10.1016/j.lithos.2017.10.001.

Martz P., Mercadier J., Cathelineau M., Boiron M.-C., Quirt D., Doney A., Gerbeaud O., De Wally E. and Ledru P. (2019a) Formation of U-rich mineralizing fluids through basinal brine migration within basement-hosted shear zones: A large-scale study of the fluid chemistry around the unconformity-related Cigar Lake U deposit (Saskatchewan, Canada). Chem. Geol. 508, 116-143. Available at: https://www.sciencedirect.com/science/article/pii/S0009254118302985 [Accessed April 25, 2019]. 

forensics. Geochim. Cosmochim. Acta 249, 138-159. Available at: https://www.sciencedirect.com/science/article/pii/S0016703719300493 [Accessed May 19, 2019].

Mercadier J., Richard A., Boiron M.-C., Cathelineau M. and Cuney M. (2010) Migration of brines in the basement rocks of the Athabasca Basin through microfracture networks (P-Patch U deposit, Canada). Lithos 115, 121-136. Available at: https://www.sciencedirect.com/science/article/pii/S0024493709004666 [Accessed April 25, 2019].

Le Mignot E., Siebenaller L., Béziat D., André-Mayer A.-S., Reisberg L., Salvi S., Velasquez G., Zimmermann C., Naré A. and Franceschi G. (2017) The Paleoproterozoic Copper-Gold Deposits of the Gaoua District, Burkina Faso: Superposition of Orogenic Gold on a Porphyry Copper Occurrence? Econ. Geol. 112, 99122. Available at: https://pubs.geoscienceworld.org/economicgeology/article/112/1/99-122/152614.

Mikulski S. Z., Markey R. J. and Stein H. J. (2005) Re-Os ages for auriferous sulfides from the gold deposits in

Morelli R., Creaser R. A., Seltmann R., Stuart F. M., Selby D. and Graupner T. (2007) Age and source 
Ondrus P., Veselovsky F., Gabasova A., Drabek M., Dobes P., Maly K., Hlousek J. and Sejkora J. (2003) Oreforming processes and mineral parageneses of the Jachymov ore district. J. Czech Geol. Soc. 48, 157-192. Available at: http://www.jgeosci.org/index.php?pg=detail\&ID=JCGS.949\%5Cnhttp://www.jgeosci.org/content/JCGS2 003_3-4_ondrus4.pdf.

Pacquet A. and Weber F. (1993) Pétrographie et minéralogie des halos d'altération autour du gisement de Cigar Lake et leurs relations avec les minéralisations. Can. J. Earth Sci. 30, 674-688. Available at: http://www.nrcresearchpress.com/doi/10.1139/e93-055 [Accessed April 25, 2019].

Pagel M. (1975) Détermination des conditions physico-chimiques de la silicification diagénétique des grès Athabasca (Canada) au moyen des inclusions fluides. Comptes Rendus Académie Sci. Paris 280, 23012304.

Petruk W. (1971) Mineralogical characteristics of the deposits and textures of the ore minerals. Can. Mineral. 11, 108-139. Available at: http://dx.doi.org/.

Philippe S., Lancelot J. R., Clauer N. and Pacquet A. (1993) Formation and evolution of the Cigar Lake uranium deposit based on U- Pb and K-Ar isotope systematics. Can. J. Earth Sci. 30, 720-730.

Raič S., Mogessie A., Benkó Z., Molnár F., Hauck S. and Severson M. (2015) Arsenic-rich Cu-Ni-PGE mineralization in Werlegs, Duluth complex, St. Louis County, Minnesota, USA. Can. Mineral. 53, 105132.

Reid K. D., Ansdell K., Jiricka D., Witt G. and Card C. (2014) Regional Setting, Geology, and Paragenesis of the Centennial Unconformity-Related Uranium Deposit, Athabasca Basin, Saskatchewan, Canada. Econ. Geol. 109, 539-566. Available at: https://pubs.geoscienceworld.org/economicgeology/article/109/3/539566/128570 [Accessed May 19, 2019].

Reyx J. and Rulhmann F. (1993) Etude metallographique des differentes associations minerales et caracterisation chimique des mineraux uraniferes du gisement de Cigar Lake (Saskatchewan, Canada). Can. J. Earth Sci. 30, 705-719.

Richard A., Cathelineau M., Boiron M.-C., Mercadier J., Banks D. A. and Cuney M. (2016) Metal-rich fluid inclusions provide new insights into unconformity-related U deposits (Athabasca Basin and Basement, 

[Accessed April 25, 2019].

Rock N. M. . and Duffy T. . (1986) REGRES: A FORTRAN-77 program to calculate nonparametric and "structural" parametric solutions to bivariate regression equations. Comput. Geosci. 12, 807-818. Available at: https://www.sciencedirect.com/science/article/pii/0098300486900312 [Accessed June 15, $2018]$.

Rosner B. (1983) Percentage points for a generalized ESD many-outlier procedure. Technometrics 25, $165-172$.

752

Saintilan N. J., Creaser R. A., Spry P. G. and Hnatyshin D. (2017) Re-Os Systematics of löllingite and arsenopyrite in granulite-facies garnet rocks: Insights into the metamorphic history and thermal evolution of the Broken Hill Block during the early mesoproterozoic (New South Wales, Australia). Can. Mineral. 55, 29-44.

Schwab D. L., Thorkelson D. J., Mortensen J. K., Creaser R. A. and Abbott J. G. (2004) The Bear River dykes (1265-1269 Ma): westward continuation of the Mackenzie dyke swarm into Yukon, Canada. Precambrian Res. 133, 175-186. Available at: https://www.sciencedirect.com/science/article/pii/S0301926804000890 [Accessed June 14, 2018].

Smoliar M. I., Walker R. J. and Morgan J. W. (1996) Re-Os Ages of Group IIA, IIIA, IVA, and IVB Iron Meteorites. Science (80-. ). 271, 1099-1102. Available at: http://www.sciencemag.org/content/271/5252/1099.short [Accessed August 8, 2014].

Stein H. J. and Hannah J. L. (2014) Tiny Molybdenites Tell Diffusion Tales. In American Geophysical Union, Fall Meeting 2014 pp. V33A-4837. Available at: http://adsabs.harvard.edu/abs/2014AGUFM.V33A4837S [Accessed August 10, 2018].

Stein H. J., Markey R. J., Morgan J. W., Hannah J. L. and Schersten A. (2001) The remarkable Re-Os chronometer in molybdenite: how and why it works. Terra Nov. 13, 479-486. Available at: http://doi.wiley.com/10.1046/j.1365-3121.2001.00395.x [Accessed August 8, 2018].

Stein H. J., Morgan J. W. and Schersten A. (2000) Re-Os Dating of Low-Level Highly Radiogenic (LLHR) Sulfides:The Harnas Gold Deposit, Southwest Sweden, Records Continental-Scale TectonicEvents. Econ. Geol. 95, 1657-1671. Available at: https://pubs.geoscienceworld.org/economicgeology/article/95/8/1657$1671 / 22042$. 
Takahashi Y., Uruga T., Suzuki K., Tanida H., Terada Y. and Hattori K. H. (2007) An atomic level study of rhenium and radiogenic osmium in molybdenite. Geochim. Cosmochim. Acta 71, 5180-5190. Available at: https://www.sciencedirect.com/science/article/pii/S0016703707004619 [Accessed August 10, 2018 ].

Theil H. (1992) A Rank-Invariant Method of Linear and Polynomial Regression Analysis. In Henri Theil's Contributions to Economics and Econometrics. Advanced Studies in Theoretical and Applied Econometrics Springer, Dordrecht. pp. 345-381. Available at: http://www.springerlink.com/index/10.1007/978-94-011-2546-8_20 [Accessed June 15, 2018].

Truche L., Joubert G., Dargent M., Martz P., Cathelineau M., Rigaudier T. and Quirt D. (2018) Clay minerals trap hydrogen in the Earth's crust: Evidence from the Cigar Lake uranium deposit, Athabasca. Earth Planet. Sci. Lett. 493, 186-197. Available at: https://www.sciencedirect.com/science/article/pii/S0012821X18302413 [Accessed January 8, 2020].

Völkening J., Walczyk T. and G. Heumann K. (1991) Osmium isotope ratio determinations by negative thermal ionization mass spectrometry. Int. J. Mass Spectrom. Ion Process. 105, 147-159. Available at: https://www.sciencedirect.com/science/article/pii/016811769180077Z [Accessed May 16, 2018].

Vugrinovich R. G. (1981) A distribution-free alternative to least-squares regression and its application to $\mathrm{Rb} / \mathrm{Sr}$ isochron calculations. J. Int. Assoc. Math. Geol. 13, 443-454. Available at: http://link.springer.com/10.1007/BF01079647 [Accessed June 15, 2018].

York D. (1966) Least-sqares fitting of a straight line. Can. J. Phys. 44, 1079-1086. Available at: http://www.nrcresearchpress.com/doi/abs/10.1139/p66-090 [Accessed December 8, 2014]. 


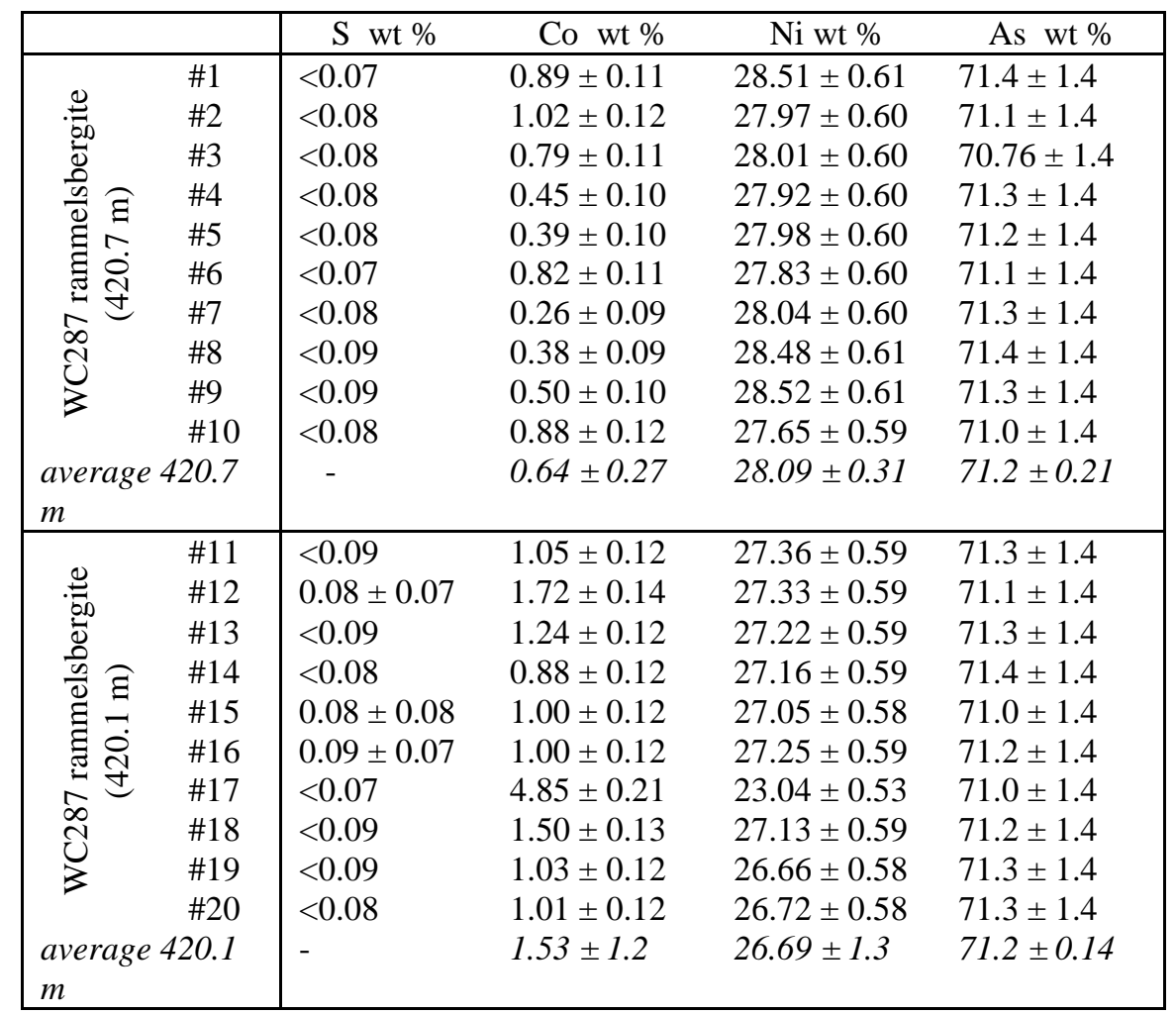

793 Table 1 Results of EMPA measurements of the rammelsbergite from 420.1 and $420.7 \mathrm{~m}$ depth levels (WC287

794 drill hole, Cigar Lake U deposit, Saskatchewan, Canada). The locations of the analyses are shown in Figure 4.

795 Uncertainty represents one standard deviation. All measurements for $\mathrm{Fe}, \mathrm{Se}, \mathrm{Sb}, \mathrm{Bi}, \mathrm{Cu}$ and $\mathrm{Mo}$ are below

796 detection limits $(0.08,0.3,0.2,0.2,0.1$ and $0.2 \mathrm{wt} \%$ respectively). 


\begin{tabular}{|c|c|c|c|c|c|c|c|c|c|c|}
\hline & $\begin{array}{c}\text { Sample } \\
\text { weight, } \\
\text { mg }\end{array}$ & $\begin{array}{c}\text { Blank } \\
\text { contribution } \\
\text { on }{ }^{187} \mathrm{Os}^{*} \\
\text { radiogenic, } \\
\%\end{array}$ & ${ }^{188}$ Os, $\mathrm{pg} \mathrm{g}^{-1}$ & ${ }^{187} \mathrm{Os} /{ }^{188} \mathrm{Os}$ & ${ }^{187} \mathrm{Re} /{ }^{188} \mathrm{Os}$ & rho & $\begin{array}{l}{ }^{187} \mathrm{Os}^{*} \text { radiogenic, } \\
\mathrm{ng} \mathrm{g}^{-1}\end{array}$ & Re, $\operatorname{ng~g}^{-1}$ & ${ }^{187} \mathrm{Os} /{ }^{187} \mathrm{Re}$ & Model age \\
\hline WC530 (457.2m) & 247 & 0.2 & $9.03 \pm 0.17$ & $94.0 \pm 1.7$ & $4443 \pm 91$ & 0.893 & $0.8465 \pm 0.0077$ & $63.48 \pm 0.58$ & $0.02112 \pm 0.00020$ & $1254 \pm 12 \mathrm{Ma}$ \\
\hline WC287 (420.0m) & 191 & 0.1 & $14.59 \pm 0.22$ & $169.8 \pm 2.6$ & $8110 \pm 140$ & 0.912 & $2.473 \pm 0.010$ & $187.1 \pm 1.3$ & $0.02092 \pm 0.00014$ & $1242.6 \pm 8.5 \mathrm{Ma}$ \\
\hline WC287 (420.1m) A & 126 & 0.03 & $30.36 \pm 0.33$ & $431.5 \pm 4.7$ & $19590 \pm 280$ & 0.774 & $13.092 \pm 0.016$ & $941.2 \pm 8.4$ & $0.02201 \pm 0.00010$ & $1307 \pm 12 \mathrm{Ma}$ \\
\hline WC287 (420.1m) B & 155 & 0.02 & $26.98 \pm 0.98$ & $554 \pm 20$ & $25910 \pm 970$ & 0.968 & $14.954 \pm 0.027$ & $1106 \pm 10$ & $0.02139 \pm 0.00010$ & $1270 \pm 12 \mathrm{Ma}$ \\
\hline WC287 (420.1m) C & 140 & 0.03 & $29.54 \pm 0.31$ & $382.6 \pm 4.0$ & $18030 \pm 200$ & 0.921 & $11.295 \pm 0.015$ & $842.7 \pm 3.7$ & $0.021211 \pm 0.000049$ & $1259.8 \pm 5.8 \mathrm{Ma}$ \\
\hline WC287 (420.1m) D & 141 & 0.04 & $8.90 \pm 0.46$ & $1038 \pm 53$ & $48600 \pm 2500$ & 0.997 & $9.231 \pm 0.016$ & $684.2 \pm 2.4$ & $0.021352 \pm 0.000042$ & $1268.2 \pm 5.0 \mathrm{Ma}$ \\
\hline WC287 (420.1m) E & 107 & 0.02 & $36.36 \pm 0.78$ & $581 \pm 12$ & $28040 \pm 610$ & 0.976 & $21.129 \pm 0.044$ & $1613.2 \pm 7.0$ & $0.020727 \pm 0.000050$ & $1231.4 \pm 5.9 \mathrm{Ma}$ \\
\hline WC287 (420.1m) F & 252 & 0.009 & $39.29 \pm 0.73$ & $565 \pm 11$ & $27330 \pm 540$ & 0.933 & $22.189 \pm 0.040$ & $1699 \pm 12$ & $0.020663 \pm 0.000074$ & $1227.6 \pm 8.8 \mathrm{Ma}$ \\
\hline WC287 (420.7m) A & 139 & 0.05 & $4.68 \pm 0.30$ & $1690 \pm 110$ & $79300 \pm 5100$ & 0.993 & $7.895 \pm 0.014$ & $586.5 \pm 4.4$ & $0.021305 \pm 0.000083$ & $1265.4 \pm 9.8 \mathrm{Ma}$ \\
\hline WC287 (420.7m) B & 136 & 0.04 & $8.26 \pm 0.45$ & $1077 \pm 59$ & $47300 \pm 2600$ & 0.998 & $8.892 \pm 0.017$ & $618.4 \pm 2.2$ & $0.022757 \pm 0.000046$ & $1350.6 \pm 5.5 \mathrm{Ma}$ \\
\hline WC287 (420.7m) C & 188 & 0.07 & $10.00 \pm 0.69$ & $392 \pm 27$ & $18400 \pm 1300$ & 0.999 & $3.921 \pm 0.012$ & $290.95 \pm 0.91$ & $0.021327 \pm 0.000047$ & $1266.7 \pm 5.6 \mathrm{Ma}$ \\
\hline WC287 (420.7m) D & 106 & 0.03 & $4.30 \pm 0.43$ & $3440 \pm 340$ & $165000 \pm 16000$ & 0.999 & $14.812 \pm 0.024$ & $1123.7 \pm 3.9$ & $0.020862 \pm 0.000040$ & $1239.3 \pm 4.8 \mathrm{Ma}$ \\
\hline WC287 (420.7m) E & 143 & 0.05 & $5.63 \pm 0.37$ & $1227 \pm 82$ & $58400 \pm 3900$ & 0.997 & $6.904 \pm 0.015$ & $520.5 \pm 2.4$ & $0.020992 \pm 0.000054$ & $1246.9 \pm 6.4 \mathrm{Ma}$ \\
\hline Henderson a & 73 & 0.2 & $3.6 \pm 2.4$ & $920 \pm 610$ & \multicolumn{2}{|c|}{$\begin{aligned} & 20000000.9999 \\
\pm & 1300000\end{aligned}$} & $3.350 \pm 0.027$ & $11280 \pm 100$ & $0.0004700 \pm 0.0000028$ & $28.21 \pm 0.34 \mathrm{Ma}$ \\
\hline Henderson $\mathrm{b}$ & 118 & 0.1 & $2.2 \pm 1.3$ & $1490 \pm 890$ & \multicolumn{2}{|c|}{$\begin{aligned} & 32000000.9999 \\
\pm & 1900000\end{aligned}$} & $3.220 \pm 0.018$ & $10930 \pm 110$ & $0.0004663 \pm 0.0000026$ & $27.98 \pm 0.31 \mathrm{Ma}$ \\
\hline
\end{tabular}

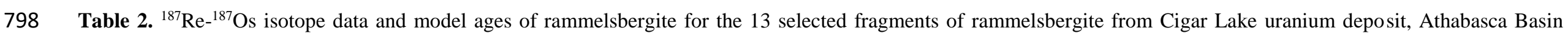

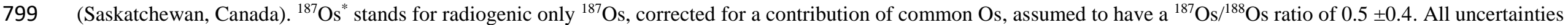

800 are 2SE. All data are blank corrected and uncertainties include the uncertainties on the blank value and on the assumed common Os isotopic composition. 


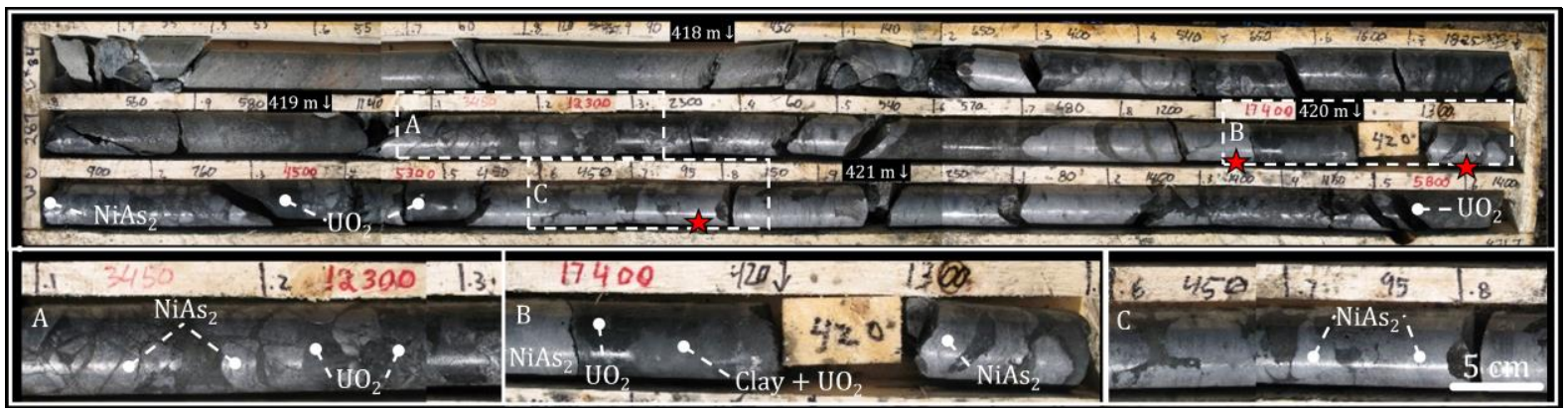

804 Fig. 1 The 417.4 - $421.6 \mathrm{~m}$ section of the WC287 drill core, Cigar Lake U deposit (Saskatchewan, Canada). A)

805 Massive $\mathrm{U}$ oxide and rammelsbergite vein at 419.1 - $419.3 \mathrm{~m}$ depth. B) Association of massive $\mathrm{U}$ oxides and

806 rammelsbergite veins at 419.9-420.1 m. C) Rammelsbergite vein at 420.6-420.8 m depth. Red stars correspond to

807 the locations of the three samples analysed (420.0, 420.1 and 420.7). The bottom part of the figure shows an 808 expanded view of each of the three sampled intervals. The number given above each interval of $10 \mathrm{~cm}$ is the total 809 counts per second of radioactivity measured by a hand scintillometer. The last sample of a massive rammelsbergite 810 vein was taken from the WC530 drillhole in the Cigar Lake deposit area, at $457.2 \mathrm{~m}$. 


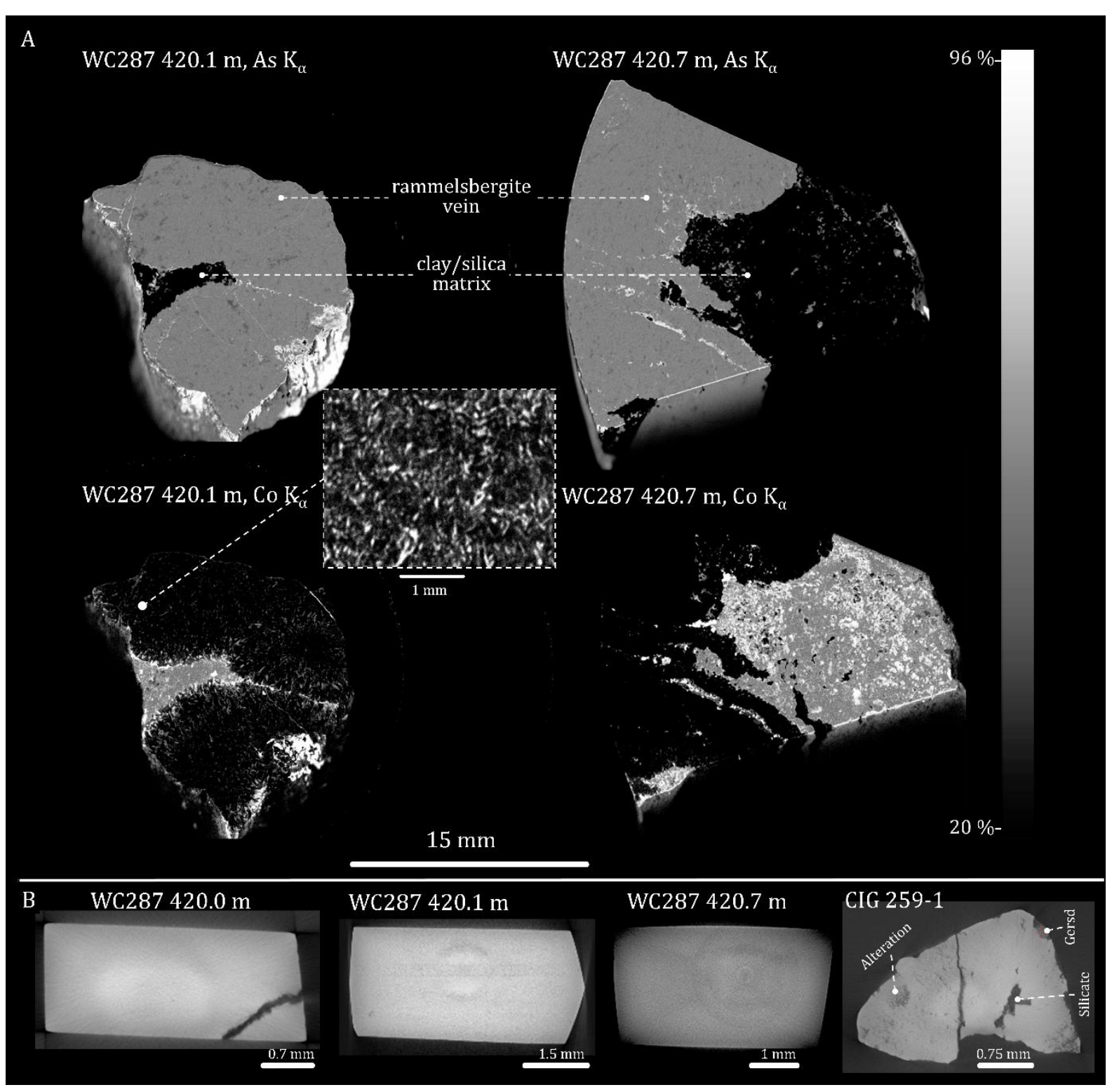

812 Fig. 2 A) $\mu$ XRF element distribution intensity maps of the two rammelsbergite samples from $420.1 \mathrm{~m}$ (left) and

$813420.7 \mathrm{~m}$ (right) depth levels of the WC287 drill core, Cigar Lake U deposit (Saskatchewan, Canada). Arsenic Ka

814 intensity distribution maps are shown on top, and Co $\mathrm{K}_{\alpha}$ intensity distribution maps are presented on the bottom.

815 The insert shows an expanded Co $\mathrm{K}_{\alpha}$ intensity distribution map measured on a pure rammelsbergite area of sample

816 WC287 420.1, free of visible clay contamination, which demonstrates an inhomogeneous distribution of Co within

817 rammelsbergite. B) Micro X-ray tomography cross-sections of three different fragments of rammelsbergite from

818 the WC287 drill hole before their dating by Re-Os analysis. The X-ray tomography demonstrates the purity of the

819 dated fragments, which can be compared with an altered fragment of rammelsbergite compromised by silicates and gersdorfitte (Gersd) from another drill hole at the Cigar Lake U deposit (CIG 259-1). 


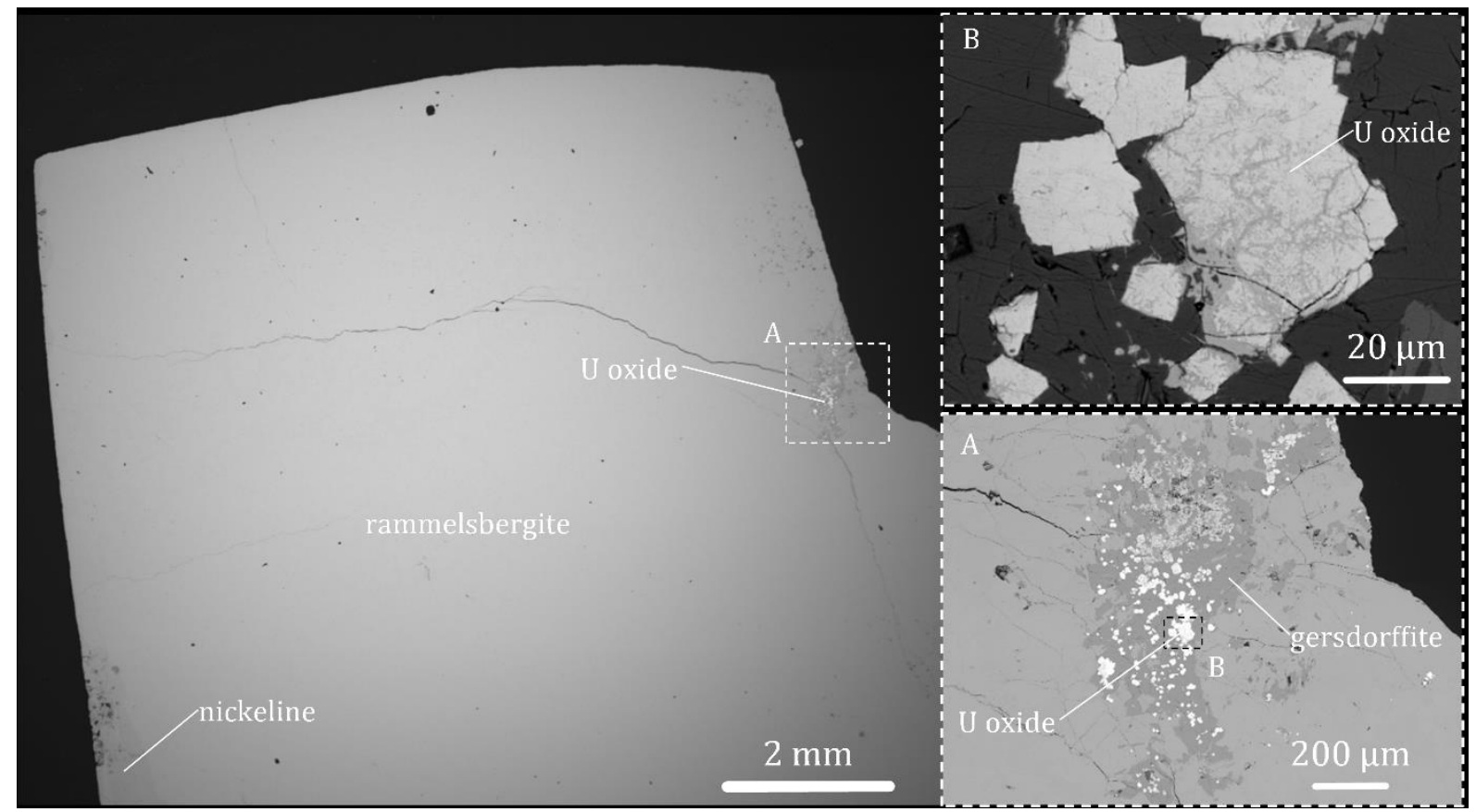

822 Fig. 3 SEM-BSE images of the massive rammelsbergite vein material from the WC530 borehole, $457.2 \mathrm{~m}$ depth,

823 Cigar Lake deposit (Saskatchewan, Canada). A - association of the rammelsbergite, gersdorffite and U oxide. B

824 - euhedral $\mathrm{U}$ oxide grains. The darker areas within the $\mathrm{U}$ oxide correspond to the $\mathrm{Pb}$ loss event (c.f. Figure 5). 


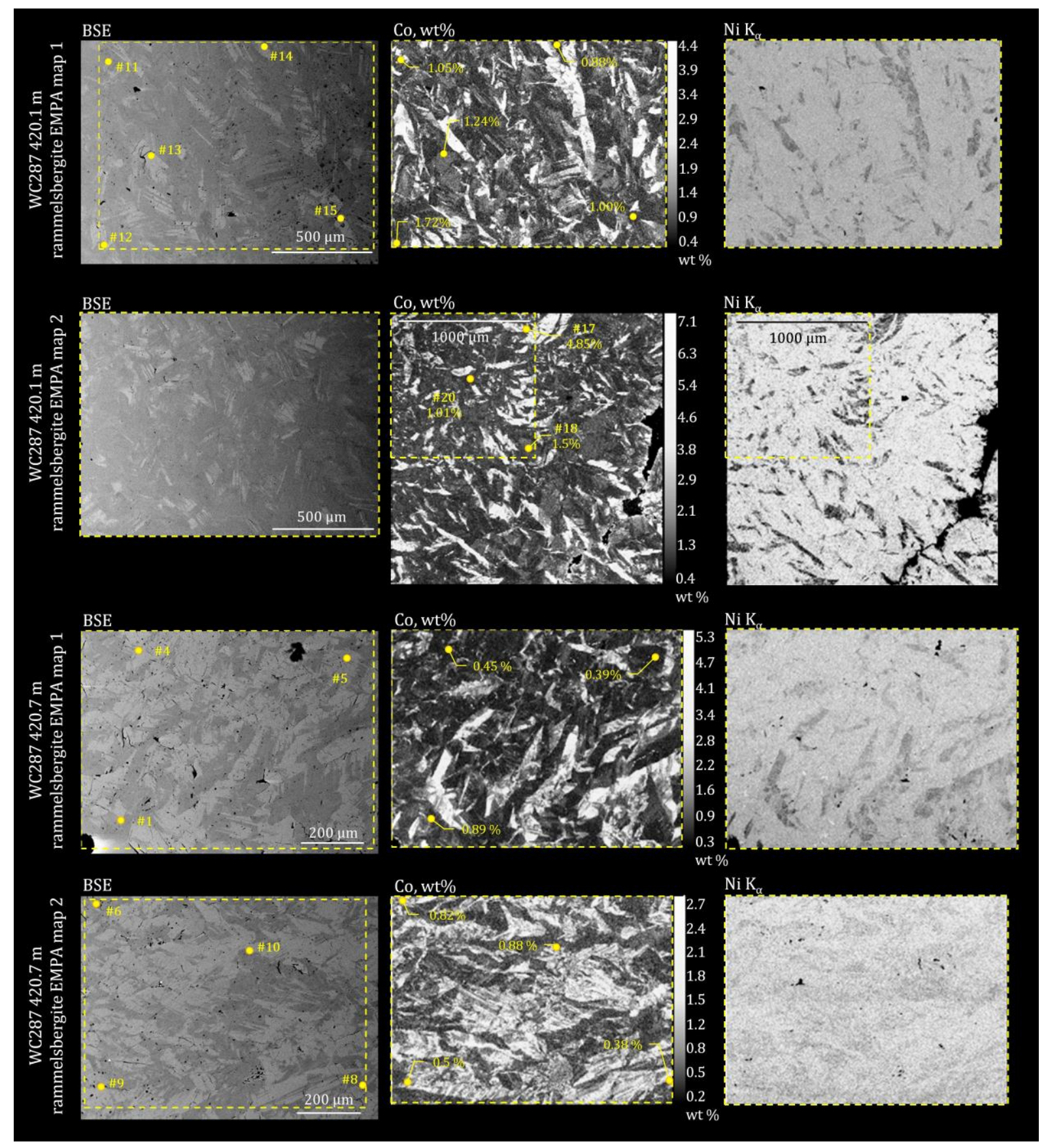

827 Fig. 4 EMPA maps and chemical analyses of 4 different locations for two samples (WC287 420.1 and

828 WC287 420.7) of pure rammelsbergite from the WC287 drill core, Cigar Lake uranium deposit, Athabasca Basin

829 (Saskatchewan, Canada). BSE images are shown to the left, and the areas corresponding to element maps (Co and

$830 \mathrm{Ni}$ ) are highlighted with yellow rectangles. $\mathrm{Ni} \mathrm{K}_{\alpha}$ intensity distribution maps are shown in the right column and

831 quantitative Co element distribution maps (in wt.\%) of the same region in the middle column. The numbered spots

832 refer to the locations where quantitative in situ spot analyses were made (Table 1). To see this figure in colour,

833 the reader is referred to the online version of the manuscript. 
data-point error ellipses are $1 \mathrm{~s}$

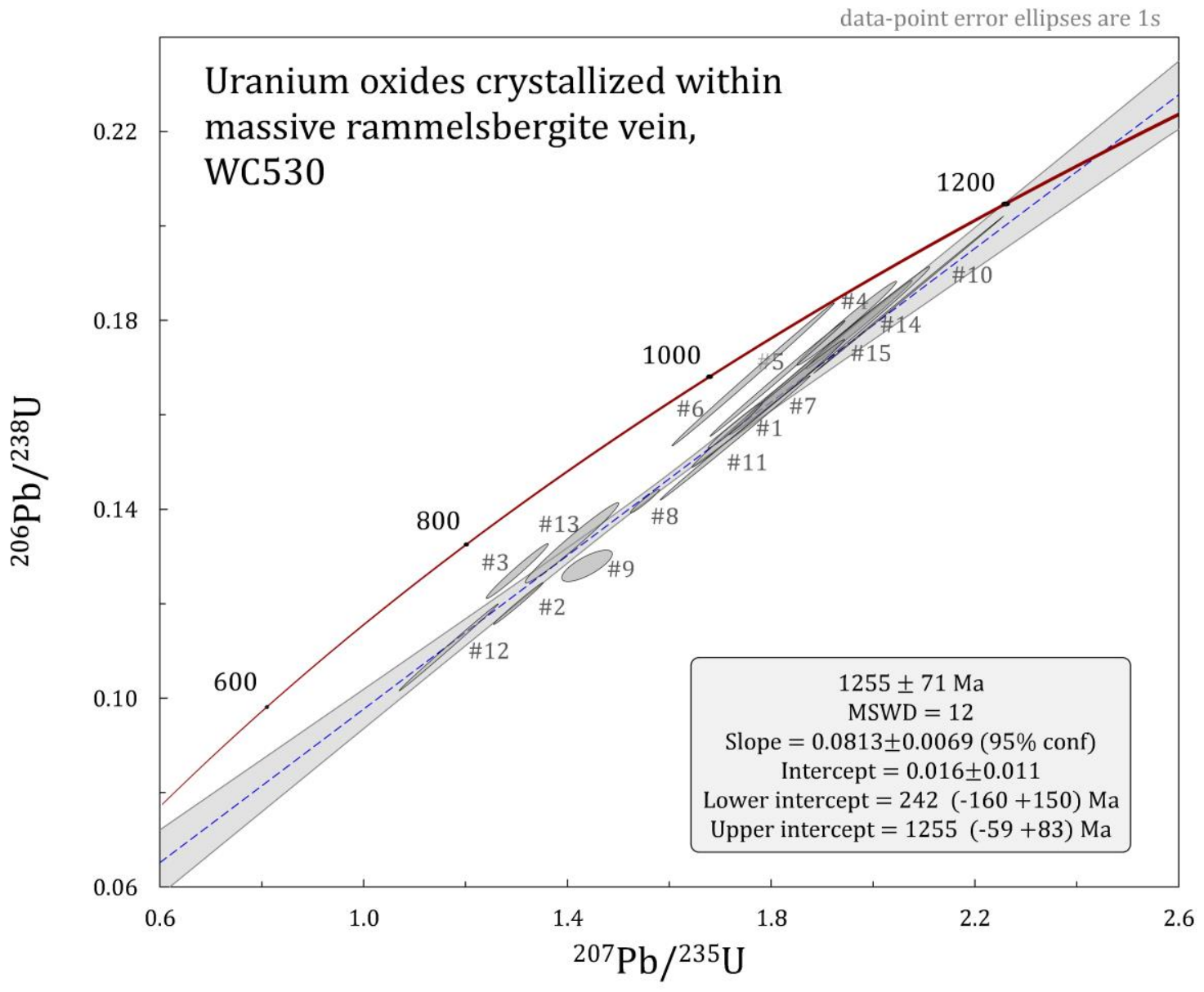

834

835 Fig. 5 Wetherill's Concordia diagram for 15 U-Pb analyses measured for the uranium oxides crystallized within

836 the massive rammelsbergite vein, Cigar Lake deposit (Saskatchewan, Canada), sample WC530, $457.2 \mathrm{~m}$ (c.f.

837 Figure 3).

838 

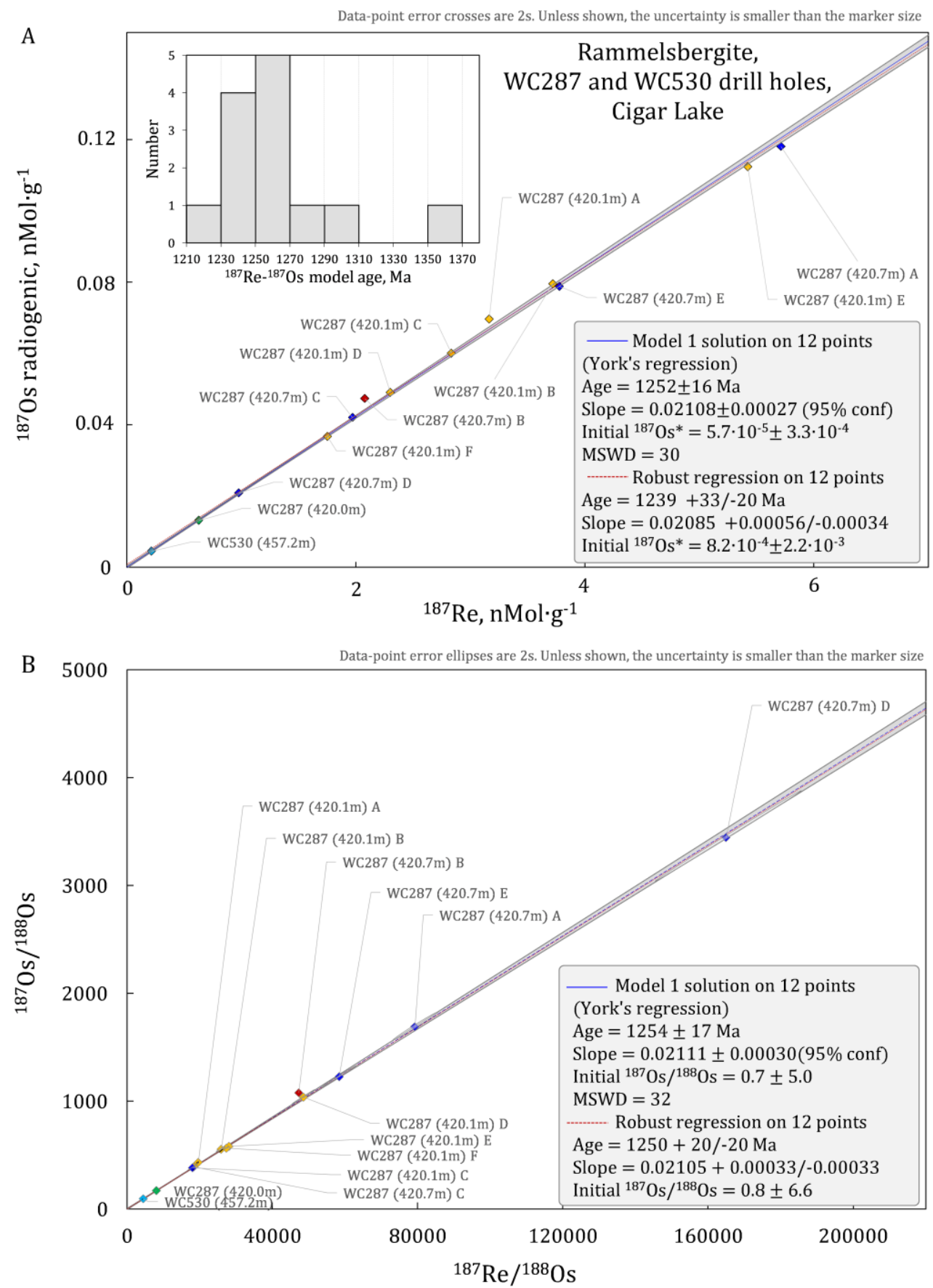

Fig. $6 \mathrm{~A}-{ }^{187} \mathrm{Re}-{ }^{187} \mathrm{Os}$ isochron plot for the 13 fragments of rammelsbergite from WC287 and WC530 drillholes,

841 Cigar Lake U deposit, Athabasca Basin (Saskatchewan, Canada). The WC287 samples from 420, 420.1 and 420.7

$842 \mathrm{~m}$ are shown with green, yellow and blue diamonds respectively, and the WC530 sample with light blue. The

843 insert in the upper left shows probability distribution histogram of the individual model ages, with a mean age of

$8441257 \pm 43 \mathrm{Ma}$ (12 individual ages, WC287 $420.7 \mathrm{~B}$ considered as outlier). Error bars represent the total 2SE

845 analytical uncertainty due to the isotopic measurements and blank corrections (see text for details). The isochron shown with the solid line and corresponding error envelope represents a solution on 12 points using regression of 
847 York (1966) excluding one outlier (WC287 420.7 B, marked in red), (calculated using model 1 of Isoplot 3.7

848 (Ludwig, 2008)). Due to the scatter of the data, which greatly exceeds that which can be explained by the assigned

849 analytical uncertainties (MSWD = 30), a robust regression solution (dashed line) is preferred. B - when presented

850 in ${ }^{187} \mathrm{Os} /{ }^{188} \mathrm{Os}-{ }^{187} \mathrm{Re} /{ }^{188} \mathrm{Os}$ isochron space, the data provide similar crystallization ages within associated 851 uncertainties. 
853 Table 1 Results of EMPA measurements of the rammelsbergite from 420.1 and $420.7 \mathrm{~m}$ depth levels (WC287 854 drill hole, Cigar Lake U deposit, Saskatchewan, Canada). The locations of the analyses are shown on Figure 4. 855 Uncertainty represents one standard deviation. All measurements for $\mathrm{Fe}, \mathrm{Se}, \mathrm{Sb}, \mathrm{Bi}, \mathrm{Cu}$ and $\mathrm{Mo}$ are below 856 detection limits $(0.08,0.3,0.2,0.2,0.1$ and $0.2 \mathrm{wt} \%$ respectively).

857

Table 2. ${ }^{187} \mathrm{Re}^{187} \mathrm{Os}$ isotope data and model ages of rammelsbergite for the 13 selected fragments of rammelsbergite from Cigar Lake uranium deposit, Athabasca Basin (Saskatchewan, Canada). ${ }^{187} \mathrm{Os}^{*}$ stands for radiogenic only ${ }^{187} \mathrm{Os}$, corrected for a contribution of common Os, assumed to have a ${ }^{187} \mathrm{Os} /{ }^{188} \mathrm{Os}$ ratio of $0.5 \pm 0.4$. All uncertainties are 2SE. All data are blank corrected and uncertainties include the uncertainties on the blank value and on the assumed common Os isotopic composition.

Fig. 1 The 417.4 - $421.6 \mathrm{~m}$ section of the WC287 drill core, Cigar Lake U deposit (Saskatchewan, Canada). A) Massive U oxide and rammelsbergite vein at 419.1 - 419.3 m depth. B) Association of massive U oxides and rammelsbergite veins at 419.9-420.1 m. C) Rammelsbergite vein at 420.6-420.8 m depth. Red stars correspond to the locations of the three samples analysed (420.0, 420.1 and 420.7). The bottom part of the figure shows an expanded view of each of the three sampled intervals. The number given above each interval of $10 \mathrm{~cm}$ is the total counts per second of radioactivity measured by a hand scintillometer. The last sample of a massive rammelsbergite vein was taken from the WC530 drill hole in the Cigar Lake deposit area, at $457.2 \mathrm{~m}$.

Fig. 2 A) $\mu \mathrm{XRF}$ element distribution intensity maps of the two rammelsbergite samples from $420.1 \mathrm{~m}$ (left) and $420.7 \mathrm{~m}$ (right) depth levels of the WC287 drill core, Cigar Lake U deposit (Saskatchewan, Canada). Arsenic $\mathrm{K}_{a}$ intensity distribution maps are shown on top, and Co $\mathrm{K}_{\alpha}$ intensity distribution maps are presented on the bottom. The insert shows an expanded $\mathrm{Co}_{\alpha}$ intensity distribution map measured on a pure rammelsbergite area of sample WC287 420.1, free of visible clay contamination, which demonstrates an inhomogeneous distribution of Co within rammelsbergite. B) Micro X-ray tomography cross-sections of three different fragments of rammelsbergite from the WC287 drill hole before their dating by Re-Os analysis. The X-ray tomography demonstrates the purity of the dated fragments, which can be compared with an altered fragment of rammelsbergite compromised by silicates and gersdorfitte (Gersd) from another drill hole at the Cigar Lake U deposit (CIG 259-1).

Fig. 3 SEM-BSE images of the massive rammelsbergite vein material from the WC530 borehole, $457.2 \mathrm{~m}$ depth, Cigar Lake deposit (Saskatchewan, Canada). A - association of the rammelsbergite, gersdorffite and U oxide. C - euhedral U oxide grains. The darker areas within the U oxide correspond to the $\mathrm{Pb}$ loss event (c.f. Figure 5). 
881 Fig. 4 EMPA maps and chemical analyses of 4 different locations for two samples (WC287 420.1 and 882 WC287 420.7) of pure rammelsbergite from the WC287 drill core, Cigar Lake uranium deposit, Athabasca Basin 883 (Saskatchewan, Canada). BSE images are shown to the left, and the areas corresponding to element maps (Co and $884 \mathrm{Ni}$ ) are highlighted with red rectangles. $\mathrm{Ni} \mathrm{K}_{\alpha}$ intensity distribution maps are shown in the right column and 885 quantitative Co element distribution maps (in wt.\%) of the same region in the middle column. The numbered spots 886 refer to the locations where quantitative in situ spot analyses were made (Table 1). To see this figure in colour, 887 the reader is referred to the online version of the manuscript.

888 Fig. 5 Wetherill's Concordia diagram for $15 \mathrm{U}-\mathrm{Pb}$ analyses measured for the uranium oxides crystallized within 889 the massive rammelsbergite vein, Cigar Lake deposit (Saskatchewan, Canada), sample WC530, 457.2 m (c.f. 890 Figure 3).

891 Fig. $6 \mathrm{~A}-{ }^{187} \mathrm{Re}-{ }^{187} \mathrm{Os}$ isochron plot for the 13 fragments of rammelsbergite from WC287 and WC530 drillholes, 892 Cigar Lake U deposit, Athabasca Basin (Saskatchewan, Canada). The WC287 samples from 420, 420.1 and 420.7 $\mathrm{m}$ are shown with green, yellow and blue diamonds respectively, and the WC530 sample with light blue. The 894 insert in the upper left shows probability distribution histogram of the individual model ages, with a mean age of $1257 \pm 43 \mathrm{Ma}$ (12 individual ages, WC287 420.7 B considered as outlier). Error bars represent the total analytical uncertainty due to the isotopic measurements and blank corrections (see text for details). The isochron shown with the solid line and corresponding error envelope represents a solution on 12 points using regression of York (1966) not taking one outlier (WC287 420.7 B, marked in red) into account (calculated using model 1 of the isoplot 3.7 (Ludwig, 2008)). Due to the scatter of the data, which greatly exceeds that which can be explained by the assigned analytical uncertainties (MSWD = 30), a robust regression solution (dashed line) is preferred. $\mathrm{B}$ - when presented in ${ }^{187} \mathrm{Os} /{ }^{188} \mathrm{Os}-{ }^{187} \mathrm{Re} /{ }^{188} \mathrm{Os}$ isochron space, the data provides similar crystallization ages within associated uncertainties. 